\title{
Esnaflara Dair Çalışmaların Kayıp Halkası: Sosyal Sermaye*
}

\author{
Arş. Gör. Nuh Akçakaya \\ Selçuk Üniversitesi, Edebiyat Fakültesi \\ Sosyoloji Bölümü \\ akcakayanuh@gmail.com
}

\author{
Arş. Gör. Mehmet Fatih Bă̆rıyanık \\ Selçuk Üniversitesi, Edebiyat Fakültesi \\ Sosyoloji Bölümü \\ fatihbagriyanik@gmail.com
}

Öz

Bu çalışmada esnafların iktisadi stratejilerinin anlaşılması için ekonomik sermayenin önemi kabul edilmektedir. Fakat burada üretim, büyüme ve küçülme süreçlerinin esnafların ekonomik sermayesinin yanında sosyal sermayesi ile de irtibatlı olduğu vurgulanmıştır. Bundan dolayıdır ki daha önceki esnaflık çalışmalarında sosyal sermaye vurgusunun zayıf kalması, burada "kayıp halka" olarak nitelendirilmiştir. Çalışma dört ana bölümden oluşmaktadır. Birinci bölümde sosyal sermayenin insan ilişkilerindeki merkezi rolü anlatılmıştır. Burada toplumsal aktörlerin arzu ettikleri psiko-sosyal konumlar için ekonomik sermayenin yanında kültürel, beşeri ve toplumsal sermayeye de ihtiyaç duyabileceği ifade edilmiştir. İkinci bölümde, esnafların sosyal sermayeyi ekonomik sermayeye dönüştürebileceği ileri sürülmüştür. Üçüncü bölümde ise esnaflığın hem kapitalizmden hem de gelenekten gelen bazı doktrinlerle kendine has bir yapıya büründüğü ifade edilmiştir. Bunun sonucunda esnafların daha çok geleneksel-informel ağları teşkil eden bir sosyal sermaye rezervinin olduğu vurgulanmıştır. Son bölümde ise Konya'da 450 esnaf ile yapılan araştırmanın bulguları analiz edilmiştir. Burada esnafların hangi ağlar ile ne yoğunlukta ilişkiye girdikleri, kendi arasındaki ilişkiler ve güven göstergeleri incelenmiştir. Son olarak ekonomik kriz zamanlarında nasıl strateji ürettikleri ve bu stratejiler için sosyal sermayeden ne denli faydalandıkları anlaşılmaya çalışılmıştır. Çalışmanın en temel sonucu, esnafların sosyal ve ekonomik sermayeleri arasında bir ilişki olduğu şeklinde olmuştur.

Anahtar Kelimeler: Sosyal sermaye, esnaf sermayesi, esnaf sosyolojisi, esnaf ilişkileri, esnaf sorunları.

\section{The Missing Link of Works on Tradesmen: Social Capital}

\begin{abstract}
In this study, the importance of economic capital for the understanding of the tradesmen economic strategies is accepted. However, it is emphasized that the processes of production, growth and contraction are linked to the social capital of the tradesmen as well as their economic capital. Therefore, the weakness of the social capital emphasis in studies of tradesmen was described here as the "missing link". The study consists of four main sections. In the first section, the central role of social capital in human relations is explained.
\end{abstract}

\footnotetext{
* Bu çalışmanın bir kısım nicel verilerinin toplanmasında emeği geçen Selçuk Üniversitesi Sosyoloji Bölümü 3. Sınıf öğrencilerine ve Konya bedesten çarşısı esnaflarından terzi Mustafa Ölmez'e aydınlatıcı fikirlerinden ötürü hassaten teşekkür ederiz. 
It is stated that social actors may need cultural, human and social capital as well as economic capital for the desired psycho-social positions. In the second section, it is suggested that tradesmen can transform social capital into economic capital. In the third section, it is stated that tradesmenness have a unique structure with doctrines deriving from both capitalism and tradition. As a result, it is emphasized that tradesmen have a social capital reserve, which constitutes mostly traditional-informal networks. In the final section, the findings of the study conducted with 450 tradesmen in Konya were analyzed. Here, the networks within which the tradesmen interact, relations among themselves and trust indicators were examined. Finally, it is attempted to understand how they produced strategies in times of economic crisis and how they benefited from social capital for enacting these strategies. The main result of the study is that there is a relation between the social and economic capital of the tradesmen.

Keywords: Social capital, capital of tradesmen, sociology of tradesmen, tradesmen relations, tradesmen problems. 


\section{GİRIŞ}

Türkiye'de esnaf ve zanaatkârlar, gerek üretim veya hizmet faaliyetlerinin yerine getirilmesi için gerekse de toplumsal katmanlar arasında sınıf, statü veya onur temelli konum kapmak için önemli ölçüde bir sermaye rezervine ihtiyaç duymaktadırlar. Yerli literatürdeki mevcut esnaf çalışmalarında, ekonomik sermayenin önemi -haklı olarakşimdiye kadar oldukça fazla vurgulanmıştır. Fakat sosyal teoride sermayenin çeşitli biçimleri olarak görülen kültürel, sosyal ya da beşeri sermayesi bağlamında esnaflığın vurgulanmamış olması, literatürde bu alanın bütün boyutları ile okunamamasına neden olmaktadır. Şüphesiz bu çalışma, söz konusu eksikliği gidermek gibi bir gayenin ürünü olarak görülmemelidir. Burada sadece standart bir okuma biçiminin üstesinden gelmenin yolları aranmaktadır. Türkiye'de daha önceki çalışmalarda iktisadi kalkınma ve sosyal sermaye ilişkisi çeşitli şekillerde vurgulanmıştır. Ancak bu ilişkisellik ağırlıklı olarak büyük işletme sahipleri üzerinden değerlendirilmiş, burada da mesele büyük oranda ekonomik kalkınma ve ekonomik sermaye arasındaki korelasyonlar üzerinden okunmuştur.

$\mathrm{Bu}$ çalışma esnafların ekonomik sistem içerisinde tutunma, büyüme ve küçülme pratiklerini mevcut ekonomik sermayesi ile olan ilişkisi bağlamında değil; esnafın sosyal sermayesi bağlamında değerlendirmek amacı ile tasarlanmıştır. Böylece eşit ekonomik sermayeye sahip olduğu varsayılan ve benzer işleri yapan esnafların neden eşit oranda büyüyemediği veya küçülmediği sorularının cevabının verilmesi, bir sosyal sermaye çözümlemesi ile daha muhtemel olacaktır. Esnafların mevcut ağları kullanma becerileri ve imkânları, yaptıkları işlere dair nihai verimi belirlemekle beraber, verimsizlik durumunda karşılaşılan krizlerin de üstesinden gelme imkânlarını belirleyebilmektedir. Bu noktada sosyal sermayesi nispetinde özellikle dayanışma ağlarını aktif bir şekilde kullanan esnaflar, bundan iki fayda elde edebilmektedir. Bunlardan birincisi, sosyal sermayenin ekonomik sermayeye tahvili olarak düşünülebilir. Bu çalışmanın asıl vurgusunu oluşturan ikinci fayda ise esnaflar, kriz zamanlarının psikolojik, sosyal ve ekonomik tahribatını sosyal sermayesi sayesinde minimize etmektedir. Bu durum Konya'nın merkez ilçelerinde 450 esnaf ile yapılan saha araştırması eşliğinde betimlenmeye çalışılmıştır.

\section{SOSYAL SERMAYENIN ÖNEMI}

10 Temmuz 1988'de İngiltere Başbakanı Margaret Hilda Thatcher'ın “biliyor musunuz toplum diye bir şey yoktur" (Aydemir, 2011, s. 1; Field, 2008, s. 10) şeklinde meşhur demecini vermesinin ardından yaklaşık 30 yıl geçmiş durumda. Bu demeç, bireyselleşme eğilimlerinin doruğa çıktığına dair politik bir itirafı ya da istenci ortaya koymaktaydı. Fakat 17 Ocak 2018 tarihi itibariyle BBC'de çıkan habere göre aynı topraklarda bugün "Yalnızlık Bakanlığı" kuruldu. Bu bakanlığa Tracey Crouch bakan olarak atandı. İngiltere'de sadece otuz yıllık bir süreç içerisinde iki farklı toplumsal dinamikten neşet eden siyasal eğilimler, modern bireyin yaşamış olduğu birçok gerilimi açıklamasının yanında, bir kısım paradigmaların pratikteki tezahürleri itibariyle yeniden sorgulandığını göstermektedir. $\mathrm{Bu}$ gerilimler öteden beri sadece İngiliz toplumunun değil, özelde Batı'nın genelde ise bütün toplumların çeşitli yoğunlukta yaşamış oldukları gerilimlerdir. Yalnızlaşmak, bencilleşmek, evsizleşmek veya soyutlanmak gibi farklı mastarlarla ifade edilen bir dizi tematik sosyopsikolojik hadise ve kavramsallaştırmaların, modernitenin bireyselleştirici telkinlerinin bir sonucu olduğuna dair oldukça fazla çalışma vardır (Bkz. Reisman, 2016; Simmel, 2009). Son zamanlarda bu içerikteki literatürün genel olarak kolektif olana ahlakilik yüklemek gibi bir misyon üstlenmesi, Batı toplumlarının üstüne inşa olduğu dünya görüşünün tekraren 
sorgulandığını göstermektedir. Özellikle postmodern söylemler etrafında kümelenen bu sorgulama eğilimleri, genellikle moderniteden hasıl olmuş bir kısım paradigmalara itiraz bağlamında, modern öncesi bireylerin kolektif yönüne dikkat çekmektedir. İlaveten son zamanlarda oluşan bir kısım literatür de kolektif olana ahlakilik yüklemekten ziyade, kolektif olanın karanlık yönüne dikkat çekmeye devam etmektedir. Fakat son kertede kolektiviteye dair yapılan soruşturmalar, bireysel bağların niteliği ve niceliği açısından önemli bir alan olarak literatürdeki yerini korumaktadır.

Weber ve Durkheim gibi ilk sosyologların belirttiği şekliyle modern insan birlikteliğinin altındaki temel saikler, günümüz toplumlarında da önemli oranda canlılığını korumaktadır. İnsan birlikteliklerinin formel veya informel şekillerde cereyan etmesini mümkün kılan işbölümü, dayanışma, uzmanlaşma, bürokrasi gibi kimi sosyal zorunluluklar; içinde yaşadığımız toplumların Thatcher'ın ifadesinin aksine, tek tek bireylerden oluşmadığını ve oluşmak zorunda da olmadığını ortaya koymaktadır. Ancak inşa edilen birliktelik formlarının değişmediğini, insanoğlunun temel ve evrensel olarak sabit bir tarz ile ilişki kurduğunu, insanlar arasındaki bağların aynı mukavemet ve zorunlulukları ihtiva ettiğini söylemek mümkün görünmemektedir. Bu noktada kurulan ilişkilerin biçim ve üslubu, bireysel ve toplumsal gerçekliğin yanında; yer ve zamanın muhteviyatına göre de değişebilmektedir. İlişkiler ve bağlantılar insan tabiatının bir gereği olarak sürekli bir şekilde yeniden inşa edilmektedir, yeniden yapılandırılmaktadır. Böylece insanlar arasındaki 'ilişkilerin önemli olduğunu' (Field, 2008, s. 1) vurgulayan "sosyal" ve "sermaye" terkibinden hasıl olmuş "sosyal sermaye" kavramının kendi önemi de ortaya çıkmaktadır. Yani başka bir ifadeyle, önemli olan bir durumu vurgulamak maksadıyla metaforikleştirilen kavramın kendisi de önemli bir hale gelmiştir.

Sosyal sermaye kavramı insanların formel veya informel ağlar vasıtasıyla çeşitli düzeylerde kurdukları ilişkilere işaret etmek için kullanılmaktadır. Bunun yanında ilişki kurmanın temel gereklilikleri hükmünde olan karşılıklı kazanç, güven, ă̆, STK vs. gibi bir dizi tematik unsurlar da sosyal sermaye ile ilişkilendirilmektedir (Putnam, 2010, s. 125). Her ne kadar da farklı misyonları ve tanımları olsa da (Tecim, 2011, s. 40) kavram ilişkilerin önemine ve kurulma biçimine işaret ederek (Field, 2008), sermaye rezervleri ile ilişkinin muhteviyatı arasındaki bağlantıları anlamaya dönük bir çabayı ihtiva etmektedir. Burada kavram çoğu zaman özsel olarak değil, işlevsel olarak tanımlanmakta (Coleman, 2010, s. 82), ilişkilerin genel doğasına ve birey-birey veya birey-kurum arasındaki ağlara gönderme yapmaktadır. Yani "sosyal sermayenin ana fikri sosyal iletişim ağlarının değerli bir servet olduğudur" (Field, 2008, s. 16). Esasında sermaye kavramının kendisinin harcanabilecek bir çağrışımla hemhal olması, ona rezerv yakıştırmasının yapılmasına neden olmuştur denilebilir. Fakat sosyal sermaye harcandıkça tükenen değil artan bir öze sahip olması dolayısıyla (Aydemir, 2011, s. 23), en azından belirgin bir şekilde ekonomik sermayeden ayrilabilecek bir özelliğe sahiptir. Bu noktada failler, birbirleri ile iletişime geçerken sosyal sermayesini kullanabilmekte ve her iletişime geçme düzeyi, özneye belirli oranda ekstra olarak sermaye katkısı sunabilmektedir.

Toplumsal aktörlerin birlikte yaşama zorunluluğundan kaynaklanan ve zorunlu ilişkileri kurmak için biriktirdikleri sosyal rezervler, onların toplumun farklı katmanları arasındaki konumunu belirleyebilmektedir. Yani sermayelerin çeşitli türde ve yoğunlukta olması, toplumsal dünyada gerçekleştirilmesi hedeflenen eylemlerin başarı şansını etkilemektedir (Bourdieu, 2010, s. 46). Grooteart (2010, s. 221-222) ekonomik kalkınma ve 
büyümenin tam olarak açılanamama nedeninin, sosyal sermayenin göz ardı edilmesinden kaynaklandığını ifade eder ve bu eksik açıklamalar için sosyal sermayeyi "kayıp halka" 1 olarak görür. Benzer bir şekilde bu eksikliği vurgulamasının yanında Bourdieu (2010, s. 6465), sosyal sermayeyi kişilerin-ailelerin üstün vasıflarını çocuklarına aktarması için bir araç olarak görür. Özellikle elit ailelerin tanışıklıklarını ve ağlarını çocuklarına devrederek, üstün pozisyonlarının 'yeniden üretilmesini' sosyal sermayesi vasıtasıyla gerçekleştirdiğine işaret eder (Field, 2008, s. 24; Bourdieu-Passerson, 2015).

Bourdieu'nun (2010) ifade ettiğinin aksine sosyal sermaye sadece eşitsizliğin yeniden üretimi için değil farklı toplumsal fraksiyonlar içerisinde de önemli işlevler görebilmektedir. Nitekim Coleman (2010, s. 82) sosyal sermayeyi herhangi bir aktörün-grubun elindeki belirli bir tür kaynak olarak görmez, onu dezavantajlı gruplar için de yararlı bir kaynak olarak görür (Field, 2008, s. 28). Yani ona herkesin sahip olabileceğine dikkat çeker. Gerçekten de sosyal sermaye, sadece belirli bir guruba tahsis edilebilecek kadar nevi şahsına münhasır bir hazine değildir. Çıkar gruplarının veya elitlerin sosyal sermayeyi üstün pozisyonlarını korumak veya yüceltmek adına kullanmaları, toplumun geride kalmış kısmının veya sınıfsal özellikleri itibariyle alt gelir gurubu üyelerinin, bu kaynağı kullanamayacakları veya kullanma yeteneğinden yoksun oldukları anlamına gelmemektedir. Hatta belirli oranda toplumsal kimlikleri itibariyle dışlanmış bir takım grupların -damgalı, siyahi, fahişe vs.kendi arasında bir ağ ve sermaye rezervi oluşturduğu görülmektedir. Bu noktada Goffman (2014) varsayılan toplumsal kimlik ve olması gereken toplumsal kimlik arasındaki gerilimi yaşayan bir kısım damga sahibi bireylerin dahi, kendi arasında çeşitli ağlar ve ilişkisellikler ile biraradılık kurabildiğini çok defa göstermiştir. Böylece normatif değer sistemi içerisinde itibarsızlaştırılmaya müsait kişiler, ekonomik sistem içerisinde alt sınıf olarak tanımlananlar veya genel olarak toplumsal sistem içerisinde zayıf, yoksun ve öteki mesabesinde olan kimi bireyler, kendi aralarında önemli ölçüde bir sermaye rezervini paylaşabilmektedirler. Sosyal sermayenin bu denli yayılışı her bireye özellikle kriz zamanlarında bireysel veya toplumsal krizlerin üstesinden gelme imkânı tanıyabilmektedir. Ancak yukarıda da işaret edildiği gibi bu sermayenin bir "karanlık tarafı" da vardır (Field, 2008, s. 101). Sapkın olarak damgalanan bir kısım grupların sapkınlıklarını sürdürmek için veya iyi niyetle sapkın olmayan ve sadece pozisyonlarını korumak isteyen kişilerin, kendi arasında bir ilişki ağı ve rezervi söz konusu olabilmektedir. Burada sapkınlığın kolektif yönü açığa çıkmaktadır. Nitekim "eğer herkangi bir insan etkinliğini kolektif bir etkinlik olarak ele alabiliyorsak sapkınlığ da bu şekilde ele alabiliriz" (Becker, 2015, s. 221). Bu noktada sosyal sermayenin varlığı bir bütün olarak toplumun her katmanında pozitif veya negatif işlevler görebilmektedir.

\section{SOSYAL SERMAYENIN EKONOMIK SERMAYEYE TAHVILI}

Yukarıda da işaret edildiği üzere, sosyal sermaye bir kısım diğer sermayelere tahvil edilebilir, dönüştürülebilir (Bourdieu, 2010; Field, 2008; Koç-Ata, 2012; Ekşi, 2009). Böylece sosyal sermaye, sıradan ilişkilerin bir harcı olmaktan çok hem sınıf, statü ve kurumların yeniden üretilmesini² sağlar hem de farklı konumlara ve pozisyonlara talip olan bireylerin bu yeniden üretimin üstesinden gelme pratiklerine imkân tanır. Mesela aristokratik olmayan

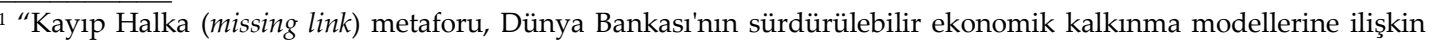
arayışlarda ortaya konulmuştur. Bu kavram ekonomik kalkınmanın fiziki ve beşeri sermaye unsurlarına indirgenmesi ile temelde eksik bırakılan ya da unutulan bir öğenin sosyal sermayenin önemine vurgu yapmaktadır" (Aydemir ve Özşahin, 2011, s. 41).

2 Yeniden üretimin sadece sosyal sermaye vasitasıyla değil sembolik ve kültürel sermaye vasıtasıyla da gerçekleştirilebildiği de görülmektedir. (bk. Bourdieu ve Passerson, 2015).
}

SEFAD, 2019; (41): 313-342 
ama imtiyazlı bir aileden gelen bir çocuk, ebeveynlerinin ağlarını ve ilişkilerini yeterince kavrayabildiği ve kullanabildiği sürece, imtiyazlı aile yapısını devam ettirebilir. Bu durum yeniden üretim olarak görülebilir ve böylece sosyal sermayenin bir eşitsizlik ürettiği varsayılabilir (Lin, 2001, s. 99). Aile üyelerinin de ötesinde toplumsal alanda konum kapmak mücadelesi içerisinde olan bireylerin, cinsiyet bazında sosyal sermayelerinin değişmesi, erkeklerin terfi ve yükselişlerini kadınlardan daha olası kılmaktadır (Fine, 2001, s. 109). Bu durum eşitsizliğin de kendi içerisinde fraksiyonlarının olduğunu göstermektedir. Öte yandan bunun aksine, işçi veya çiftçi bir ailenin çocuğu, anne-babasından devraldığı zayıf ağların ve ilişki kurabilme becerilerinin üzerine bir şeyler koyma iradesini gösterirse; yeni bir konum kapma mücadelesinde daha fazla başarı sağlayabilir. Fakat bu durum tabii olarak toplumsal tabakaların geçirgenliği ile yakın bir ilişki içerisindedir. Yeni bir konum kapma mücadelesinin Hindistan gibi yerlerde çok daha zor olduğu bilinmekle beraber, Türkiye gibi tabakaların daha geçirgen olduğu ülkeler, bireylere sosyal sermayelerini daha aktif kullanma imkânını tanıyabilmektedir. Bunun yanında geçirgen olmayan toplumsal tabakalar içerisinde de kişiler kendi farklılığını sermaye rezervleri vasıtasıyla ortaya koyabilmektedir. Mesela siyahîler içerisinde siyahî bir lider olarak farklılaşmak ya da aynı kast sistemi içerisinde diğerlerinden farklı bir pozisyonda bulunabilmek bu duruma örnek olabilecek niteliktedir.

Sosyal sermaye kavramının işaret ettiği bir kısım rezervleri nitelemek için kullanılan kavram, 20.yy ortalarında 'insani-beşeri sermaye' terkibi altında şekillenmişti. Beşeri sermaye kavramin ilk olarak kullanan Theodore W. Schultz (1961, s. 1), kavramı işçilerin bilgi ve becerilerini kullanması ile başarı oranları arasındaki bağlantıyı çözümlemek için kullanmıştır. Sermayenin soyut kullanımları daha sonraları da devam etmekle beraber sosyal sermaye kavramı; beşeri, kültürel ve sembolik sermaye kavramlarının işaret ettiği bir kısım gerçekliklere de işaret etmiş, bu sermayelerin kapsadığı alanlar kimi zaman iç içe geçmiştir. Birbirinden net olarak ayrılamayan soyut sermaye kavramsallaştırmaları çoğu zaman ekonomik sermeye ile bağdaştırılmış, bu sermayelerin birbiri için geçirgen olduğu vurgulanmıştır. Esasında bu sermayelerin geçirgenliğinin temel sebebi, özellikle ekonomik olanın sosyal olanın içerisinde gömülü olması ile alakalıdır (Marcuello-Servós, 2007, s. 201). Ekonomik sermayenin mi diğer sermayeleri zenginleştirdiği, yoksa diğer sermayalerin mi ekonomik sermayeyi belirlediği dikotomik bir tartışmadır. Son kertede bu geçişkenliğin karşılıklı olarak diyalektik bir süreci ihtiva ettiği söylenebilir. Bu manada özellikle sosyal sermayenin ekonomik sermayeye dair olumlu bir katkısının olabileceğini dillendiren sosyologlardan birisi Bourdieu'dur. Ancak Bourdieu aynı şeyi kültürel sermaye için düşünmez ve kültürel sermayenin ekonomik sermayeyi tam olarak yansıtmayabileceğini iddia ederken (Field, 2008, s. 19), bu sermayelerin birbirinden tamamen müstakil olduğunu da kabul etmez.

Sosyal sermaye incelemelerinde alt parametreleri teşkil eden ağlar, ilişkisellikler, güven, mütekabiliyet, eğitim ve kişinin içerisinde bulunduğu diğer birçok sosyo-psikolojik değişken, insanoğlunun ekonomik faliyetlerinde de oldukça fazla önem teşkil etmektedir. Bu değişkenlerin birey lehinde olması, bireylerin pazar alanı içerisinde daha aktif biri olarak faliyet yürütmesini sağlamaktadır. Zamanında büyük sermayeleri işlemiş ama iflas etmiş bir iş adamının, ekonomik sermayesini tamamen kaybettikten sonra, kısa süre içerisinde tekrardan belirli oranda bir ekonomik sermayeyi kazandığına dair oldukça fazla örnek söz konusudur. Burada iflas eden iş adamı geçmişte kurduğu ağları, tesis ettiği güveni, sahip olduğu ilişkileri ve hatta belki de 'hatır-gönül meselelerini' tekrardan devreye sokarak 
ekonomik sermayesini geri kazanmak adına bir kısım teşebbüslerde bulunup nihai amacına ulaşabilmektedir. Fakat aynı iş adamı piyasanın itimadını kaybedip 'güven krizi' yaşamaya başladığında tam tersi bir durum da olabilir. Buna benzer örnekler, tam olarak sosyal sermayenin ekonomik sermayeye tahvilini açıklaması açısından önemlidir. Burada Woolcock'un meşhur ifadesi bir kez daha önemini ortaya koymaktadır. Yani, "önemli olan neyi bildiğin değil kimi tanıdığındır" (Woolcock, 2013, s. 1258'den aktaran Aydemir, 2011, s. 28). Ekonomik sermaye ile sosyal sermaye ilişkisinin, sadece iş adamları için değil Türkiye'de esnaflar için de ayrı bir başlık altında incelenmesi gerekir. Çünkü esnaf veya büyük işletme sahiplerinin sahip olduğu sermaye rezervleri doğası itibariyle birbirinden farklıdır. İlişki kurma biçimleri ve ağların yapısı bu doğayı önemli ölçüde belirleyebilmektedir. Bu noktada esnafların sosyal sermaye rezervlerini nasıl kullandığını anlamak için öncelikle Türkiye'de esnaf ve zanaatkârlığın ele alınması gerekmektedir.

\section{TÜRK ESNAFININ SOSYAL SERMAYESINII ETKILEEYEN YAPISAL HUSUSLAR}

Modern işletmelerin oluşumunda önemli bir faktör olarak bilinen esnaf ve zanaatkârlık hem teknik olarak hem de kültürel olarak Anadolu'da ekonominin omurgası olan fabrikaların ortaya çıkışına zemin hazırlamış, hatta kimi esnafların daha sonra birer fabrikatör olarak anıldığı görülmüştür. Ancak bunun yanında halen esnaf olarak hayatına devam eden aktörlerin icra ettiği işler, kapitalist ekonomik sistem içerisinde yapısal ve kültürel özellikleri itibariyle önemli bir değişim geçirmiş; esnaflık sistemini düzenlemek, yapılandırmak ve ıslah etmekle memur, kurum ve kuruluşlar sürekli olarak farklı isim ve örgütlenmeler ile söz konusu esnafı ve esnaflığı dönüştürmüştür (Aydın, 2014, s. 33-35). Fakat bilinen sosyolojik doktrin odur ki, bireylerin ve kurumların tarihsel süreç içerisinde her yeniden yapılandırılışı, bir önceki birey ve kurumdan tamamen müstakil bir yapılandırmayı teşkil etmemektedir. Dolayısyla esnafın ve esnaflığın bugünkü değişmiş tipi önemli ölçüde bir tarihsellik de barındırmaktadır (Uysal, 2016, s. 50-51). Bunun yanında esnaflar, eylemleri için sürekli olarak yapılaşan ve kurumsallaşan esnaflık kurumuna -yani bir yerde esnaflık terbiyesi de denilebilen değerler bütününe- referansta bulunmaktadır. Esasında Aydemir'in (2016, s. 15) de ifade ettiği üzere, toplumsal tiplerin bir tip olarak kavranmasının önemli koşullarından birisi söz konusu bireyin, kurumsallaşmış yapıyla özdeş bir eylem alanının olup olmadığı ile ilgilidir. Dolayısıyla bir aktörün esnaf olarak tanımlanmasındaki ölçütler, esnaflığa ya da esnaflık terbiyesine hasredilen bir dizi kurumsallaşmış eylemin, aktör tarafından ne denli icra edilip edilmediği ile yakın bir ilişki içerisindedir. Çünkü toplumsal tipler çoğu zaman tipikleşmiş davranış kodları üzerinden bir toplumsal tip olarak kavranmaktadır.

Türkiye'de esnaf ve zanaatkâr denildiğinde akla gelen bir dizi kurumsallaşmış eylemlerin varlığ geçmişten referans almakla beraber bu eylemlerin günümüz toplumunun temel dinamikleri konumunda olan bir kısım sosyolojik olgulardan da referans alabildiği bilinmektedir. Bu noktada hem geleneksel olanın hem de modern -belki de postmodernolanın telkinleri etrafında zaman zaman bir gerilimin, zaman zaman ise bir dönüşüm ve uyuşmanın neticesinde eskiye nazaran yeni bir esnaflık kültürü ortaya çıkmıştır denilebilir (Akgül, 2017; Aslanderen, 2016). Bu yeni kültür hem insani ilişkilerin doğasını hem de salt bir ekonomik uğraşım alanı ve işbölümü fraksiyonu olarak esnaflığın ekonomik düzlemini önemli ölçüde etkilemiş, ondan etkilenmiştir. Bu noktada esnafların bir kısım alışkanlarının hangisinin geleneksel olandan hangisinin de modern olandan emareler taşıdığını tartışmaya açmak gerekmektedir.

SEFAD, 2019; (41): 313-342 


\section{Geleneğin Esnaflık Ahlakı İle İlişkisi}

Türkiye'de Osmanlı'nın son zamanlarından bu yana kadar devlet yönetimi, kurumlar, vakıflar, aile, eğitim, ekonomi, sanat ve daha birçok alan için modernleşmenin serencamı, literatürde geniş bir şekilde tartışılmıştır. Bugün modernleşme hadisesinin hem kurumlar hem de kişiler bazında neleri getirip götürdüğü yaygın bir şekilde bilinmekte, bügünün Türkiye'sinde ilerleme ve gerileme olarak işaret edilen bir kısım unsurlar doğrudan ya da dolaylı olarak moderleşme hamlelerine bağlanmaktadır. Modern Türkiye'nin ekomisine dair bir kısım insani, iktisadi ve ahlaki kazanımlar, kayıplar veya en genel anlamıyla dönüşümler; önemli ölçüde tarihin köşe taşları mesabesinde olan kimi politik duruş ve angajmanlar ile irtibatlandırılmaktadır. Esnaflık şeklinde kurumsallaşmış eylem, tavır, düşünce veya değerler silsilesi söz konusu modern ekonomik dönüşümlerden önemli ölçüde kendi üzerine düşeni almıştır. Fakat bir tarihsellik arz eden esnaflık tipolojisi; 'gelenekten, tarihten yani öncesi ile olan irtibatından' tamamen bağımsız düşünülmemektedir (Şen, 2009, s. 2). Bu noktada esnaf diye nitelendirilen toplumsal tip, halen önemli ölçüde geleneksel olanın görece veya tedrici temsilcisi olarak karşımıza çıkabilmektedir. Buna benzer bir şekilde Anadolu'da oluşan sermaye birikimi, tarihsel süreç içerisinde zanaat faliyetleriyle önemli ölçüde irtibatlandırılmakta (Özuğurlu, 2008, s. 224), esnaf ve zanaatkârların ekonomik birikimleri bugünün Türkiye'sinde ciddi bir kapitalist birikim oluşturmaktadır.

Esnafların kendi işine dair tutumlarındaki geleneksel eğilimleri şüphesiz bir bütün olarak genelleme imkânı sağlamamaktadır. Ancak özellikle ahlak, gelenek, dayanışma veya yardımlaşma gibi bir dizi sosyolojik fenomenler günümüz esnafının bir kısmının bağlılıkla sürdürmeye çalıştı̆̆ı unsurlar olarak karşımıza çıkmaktadır (Akgül, 2017; Aslanderen, 2016; Uysal, 2016). Kişilik, yaş, cinsiyet, zaman ve mekan gibi hususiyetlere bağlı olarak değişkenlik gösteren bu unsurlar, araştırmalara göre kimi esnafta bir emare şeklinde, kimilerinde ise bir ritüel şeklinde halen mevcuttur. Bunun yanında esnaflık olgusu içerisinde yüzyüze ilişkilerin daha samimi olduğu, aile içi dayanışma yoğunluğunun fazlalığı, patronluk profilinin daha farklı sergilendiği, kişinin yaptığı işe dair beslemiş olduğu duygusal yakınlığın daha fazla olduğu da bilinmektedir (Şen, 2009, s. 8). İlaveten esnaflar, birçok noktada geleneksel olanın temsiliyetini sağlayabilmekte; müşteri, çalışan, meslektaş, komşu, aile üyeleri veya akraba gibi bireysel ağ ve ilişkilerin, çeşitli düzeylerde kurulduğu kişilerle farklı bir üslup eşliğinde ilişki kurabilmektedir. Bu noktada büyük işletmeler veya kurumlarda çalışan kişilerle esnaflar kıyaslandığında, esnaflık tipolojisi daha net anlaşılmaktadır.

Müşteri ile pazarlık yapmak; işçilerle olan ilişkilerin formel değil informel bir şekilde olması; aile üyelerinin olağanüstü dönemlerde işçi olarak çalışması ve aile üyelerinin hepsine 'joker işçi' nazariyesi ile bakılabilmesi; kartsız, senetsiz, kefilsiz borca verme alışkanlığının büyük işletme sahiplerine göre çok daha fazla olması; düğün, cenaze, bayramlaşma gibi merasimlere daha fazla katılımın olması, esnaflıkla bağdaştırılabilen unsurlardandır. Bu gibi normatif hasletlerin önemli oranda geleneksel, ahlaki ve dini referans kaynakları etrafında kümelenen esnaflık kültürü ile ilintili olduğu bilinmektedir (Uysal, 2016). Ancak esnaf olarak nitelendirilen kişilerin bu kültürel ve normatif hususlara bağlllığı yukarıda da ifade edildiği gibi kişinin sosyo-psikolojik gerçekliğine bağlı olarak değişkenlik arz edebilmektedir. Hatta Türkiye'de özellikle neo-liberal ekonomi politikaların bir sonucu olarak esnaflık kültürünün ve esnaf tipinin önemli oranda değiştiği söylenebilir. 1980'lerden sonra değişen bu yapı genel olarak ekonomik büyüme, mal, üretim, tüketim ve 
para döngüsünün artışına bağlanabilir. Esnafların rekabet şartlarının daha zor bir hale gelmesi (Baykul, 2009, s. 36), Marcuse'un (1990) her insan için ifade ettiği, nitekim esnaf ve ailesi için de geçerli olan koşullandırılmış yeni ihtiyaçların ortaya çıkışı, belki de hırs ve haz istidadının görünür kılınması, hemen her aktörde olduğu gibi esnafların da insani ilişkilerinde bir kısım değişimlere neden olmuştur denilebilir. Bu noktada modern ekonomik sistemin kültürel ve geleneksel olan ile mücadelesi hayatın her alanında olduğu gibi esnaflık kurumunda da söz konusu olmuştur.

\section{Modern Ekonomik Sistemin Esnaflığı Dönüştürmesi}

Esnaflık tipinin geleneksel bir kısım kodlar vasıtasıyla kolektif olana değer verdiği, ilişkilerinde insani, ahlaki ve kültürel bir duruş ile eski olanın temsilcisi olabildiği söylendi. Ancak bunun yanında modern kapitalist sistemin bütün bir ekonomik hayat üzerinden bireysel ilişkileri etkilediği, en mikro sosyolojik fenomenden toplumsal yapının tamamına kadar baskın ve belki de başat bir rol oynadığı bilinmektedir. Literatürde fazlaca tartışılmış olan kapitalist sistemin burada tekraren tartışmaya açılması anlamsız olacaktır. Ancak Özal sonrası Türkiye' de gerçekleşen ekonomik büyümenin (Gökçen, 2013) hem ekonomik hem de kültürel bir fenomen olarak esnaflığı önemli ölçüde etkilediği ve dönüştürdüğü vurgulanmalıdır. $\mathrm{Bu}$ açıdan genel olarak kapitalist sistemin ekonomik açıdan küçük işletmeleri ve esnafları hangi bunalımlarla karşı karşıya getirdiği de bilinmektedir. $\mathrm{Bu}$ bunalımların sebeplerine değinmekten ziyade onların sonucu olarak görülebilecek insan ilişkilerini incelemek bu çalışmanın amaçlarını gerçekleştirmesi açısından daha anlamlı görünmektedir.

Kapitalist öğreti ile küçük üreticilerin yaşamış olduğu gerilimin bazı toplumsal değişmelere teşne olduğu Marksist literatürde daha önce pek çok kez tartışmaya açılmıştır. Şüphesiz Türkiye de bu değişimlerin önemli bir muhatabı olarak karşımıza çıkmaktadır. Türkiye'de esnafların güven temelli ilişkilerinin çıkar temelli ilişkilere doğru kayması; eskisine oranla müşterilere, işçilere veya STK'lara daha az güvenmesi (Yetim, 2005, s. 104), en azından geleneksel telkinlerin halen güçlü olmadığını göstermektedir. Öte yandan kredi kartının yaygın bir şekilde kullanılmaya başlanması, krizin olduğu ve olağanüstü dönemlerde esnafların yakın çevre, dost akraba vs. değil de bankalardan kredi alması, bir güvensizlik göstergesi olarak okunabilir. Fakat bunun yanında akrabalık bağlarının ve yüzyüze olan ilişkilerin, sivil toplum örgütleriyle kurulan ilişkilere göre çok daha yoğun olması, Türkiye'de formel ağlardan ziyade informel ağların işlerliğini ortaya koymaktadır. Yoğun bir sosyal sermaye rezervine sahip bireylerin bankalardan ziyade ilk olarak başvuracağı ağın aile, yakın akraba, komşu vs. şeklinde informel ağları teşkil etmesi bir yana; bu kişilerin sosyal sermayesinin yetersiz olması onu bir şekilde banka, ajans vakıf vs. gibi formel ağlara yönlendirmektedir. İnsanları birbirine bağlayan ağların körelmesi formel ağlar olarak tabir edilen ve daha çok modern zamanların ürünü olan kurumsallaşmış yapilara sevketmektedir.

Modern kapitalist sistemin esnaflı̆̆a etkilerini çeşitli parametreler üzerinden değerlendirmek mümkündür. Burada dikkat çekici bir diğer husus mekânsal sorunlardır. Modern ekonomik öğretinin bir şekilde yaratmış olduğu AVM kültürü, esnaflar için ciddi birer mekân problemi olabilmektedir. Esnaflar, mekânsal imkânsızlıklar ve kurumsallaşamama durumlarından ötürü yine çeşitli gerilimler yaşayabilmektedirler. Bir şehirde büyük bir AVM'nin yapılması belki 500 belki de 1000 esnafın boşa çıkmasına neden olabilmektedir. Söz konusu şehre yapılan AVM, ulusal ya da küresel sermayedarları o 
şehrin yerli esnafının kazandığı paraya ortak edebilmektedir. Şüphesiz bu problemleri çözmek için çeşitli zihinsel pratikler geliştiren esnaflar, yukarıda zikredilen sermaye çeşitlerini kullanmak için çabalamakta ve söz konusu sistem içerisinde tutunma pratikleri geliştirmektedir. Bu noktada sadece ekonomik değil sosyal sermaye kavramı da esnafların içinde bulunmuş olduğu sorunları çözme adına bir işlev görmektedir. Ekonomik sermayenin tükendiği, yetemediği veya olmadığı yerlerde esnaflar sosyal sermayesini devreye sokmakta, sosyal sermayesi ile hem ekonomik hem de psiko-sosyal sorunların üstesinden gelmek için ağlar, ilişkiler ve bağlantılar kullanmaktadır. Bu ağlar biçim ve içeriğine göre yatay, dikey, bağlayıcı, birleştirici, köprü kuran, zayıf veya güçlü olarak çeşitli düzeylerde kavramsallaştırılabilmektedir (Yüksel, 2015, s. 20-21). Ancak bu çalışma için ayrımların en başında, ağların formel veya informel bir nitelik taşıyıp taşımaması gelmektedir (Ergin, 2007, s. 12).

\section{Gelenek ve Kapitalizm Arasında Esnaf: Ağların Muhtevası}

Ekonomi ile sosyal sermaye arasında çeşitli düzeylerde pozitif bir ilişkinin olduğuna inananlar vardır (Ekşi, 2009, s. 86-87; Koç -Ata, 2012, s. 207-208). Sadece sosyal sermaye değil genel anlamda beşeri sermaye (Eser-Gökmen, 2009, s. 47) veya sermayenin soyut biçimleri olarak görülebilecek diğer sermaye türlerinin de ekonomik kalkınma ile yakın bir ilişkisi söz konusudur. Bu durum doğal olarak Türkiye'deki esnaflık profili için de geçerlidir. Güçlü ağ ve ilişkiler kurabilen esnafların bulundukları yöre içerisinde diğer esnaflar nispetinde daha fazla ekonomik kazanç elde ettiği bilinmektedir. Büyüyen esnafın yeni ilişki ve ağ zeminleri hazırlayarak ağlarını sürekli olarak zenginleştirmesi bu sürecin dikotomik değil diyalektik yönünü ortaya koymaktadır. "Para parayı çeker" deyiminin 'ilişki ilişkiyi' çeker veya 'ağ ağı doğurur' suretinde yeniden tecessüm etmesi sosyal sermayenin tarafları olarak addedilebilecek kişi-kurum veya kişi-kişi arasındaki diyalektik yani süreğen ilişkiyi daha anlaşılır kılması bakımından önemlidir.

OECD, Dünya Bankası veya uluslararası düzeyde sosyal sermaye araştırmaları yapan muhtelif kurumlarda, Türkiye'nin sosyal sermaye rezervleri oldukça düşük çıkmaktadır. Bu araştırmaların bir dizi metodolojik ve dilsel problemleri olmasının yanında, Ardahan (2014, s. 41) bu durumu Türk insanının yeterince tanınamamasına bağlamaktadır. Bu verilere diğer itirazlar ise araştırma değişkenlerinin ve belirlenen sosyal sermaye göstergelerinin Türk insanı için geçerli olmaması üzerinden dillendirilir. Ulusal ve uluslararası araştırmalarda özellikle güven endekslerinin oldukça düşük çıkması temelde çeşitli sebeplere bağlanabilmekle beraber burada hukuk kurumunun işlerliği de güven endekslerini belirleyebilmektedir. Batılı anlamda kurumsallaşmış hukuk mekanizmalarının olmayışı, vatandaşların özel veya tüzel kişilerle yaşadığı sorunların mahkemelerce geç çözüme kavuşturulması veya formel olarak uzlaştırma işlevi gören kurumların olmayışı, Türkiye'de kişilerin güven göstergelerine dair rakamları etkileyebilmektedir. Kişiler, mahkeme salonlarında hak arayışından ziyade muhataplarına karşı temkinli ve ölçülü bir şekilde davranmaktadırlar. Aynı güven endekslerinin ikincil ilişkiler değilde birincil ilişkiler bazında oldukça yüksek çıkması, hatta bu oranların dünya ortalamasının çok üzerinde olması, esasında Türkiye'deki güven sorularının kurum kişi ve olgu bazında değişkenlik gösterdiği anlamına gelmektedir. Mesela Türkiye'de aileye güven endeksi dünyanın birçok ülkesinden daha yüksek bir seviyede görülürken ayn güven insanların geneli veya tüzel kişiler için söz konusu olmamaktadır. 
Esnaflar -Türk insanının genelinde de söz konusu olduğu gibi- birincil ilişkilerini yoğun olarak gerçeleştirdiği topluluklarda, güven esaslı davranış tarzına sahiptirler. Bu minvalde esnafların sosyal sermayesi Batı ülkelerindeki genelgeçer göstergelerden müstakil bir şekilde anlaşılmaya çalışıldığında daha net kavranacak niteliktedir. Nitekim Türkiye'de vakıf, dernek, oda gibi çeşitli şekillerde isimlendirilen kurumsallaşmış mekanizmalar, esnafların sosyal sermayesini yansıtmamakta; hatta esnafların çoğunluğu bu gibi formel kurumlara karşı oldukça mesafeli yaklaşabilmektedir. Bu kurumlardan bazılarının periyodik aralıklarla almış olduğu aidatlar Türkiye'deki mevcut esnafın özellikle odalara karşı yaklaşımını aleyhte bir yöne doğru götürmektedir. Bir kısım esnafların resmi olarak tanınabilmesi ve çeşitli belgeleri alabilmesi için bu kurumlara kayıt yaptırma zorunluluğunun olması, esasında STK işlevi görmesi beklenen kurumların bir gönüllülük esasına değil de bir zorunluluk esasına dayalı olarak üye topladığını göstermektedir. Dolayısıyla esnaflar özelinde formel kurumların sayısal çoğunluğunun ve üye sayısındaki çoğunluğun bir sosyal sermaye göstergesi olarak değerlendirilemeyeceği ortaya çıkmaktadır.

Kurumsallaşmış düzeydeki formel veya informel dayanışma ağlarına olan tevccühün yokluğuna veya azalmışlığına rağmen, Türkiye'de esnaflar çeşitli düzeylerde ağlara sahiptirler. Bu ağlar aile, akraba ve komşu gibi daha çok güven ve birincil ilişkilere dayalı olma özelliğini taşımaktadır. Esnaflar özellikle kendi ailesi ile geliştirdiği ilişkiler vasıtasıyla ekonomik, psikolojik ve sosyolojik bir kısım sorunların üstesinden gelmektedirler. Nitekim Türkiye'de aile sosyal sermaye için "özel bir öneme" sahiptir (Aydemir-Özşahin, 2011, s. 56). Psiko-sosyal ve ekonomik kriz zamanlarında karşılaşılan problemlerin üstesinden gelmek için başvurduğu ilk ağın aile olması, esnafların sosyal sermayesi rezervinde aile ilişkilerinin önemli bir yer tuttuğunu göstermektedir. İlaveten özellikle büyük işletmelere doğru evrilmiş esnaf kökenli işletmelerin temelde bir aile işletmesi hüviyetinde olması Türkiye'deki görece güçlü aile bağlarının ekonomik alandaki tezahürü niteliğindedir. Bu noktada Türkiye'de aile şirketleri ekonomik açıdan başarılı olarak ifade edilebilir (Aydemir-Tecim, 2012, s. 45). Ancak burada Güler Sabancı'nın "Aile Şirketlerine Küresel Bakış" adlı konferansında yaptığı giriş konuşması, diğer bir önemli hususu ortaya koymaktadır. Sabancı'ya göre "Türkiye'deki işletmelerin yüzde 95'ini aile şirketleri oluşturuyor. Türkiye'de aile şirketlerinin ortalama ömrü 25 yıl. Bu aile şirketlerinin sadece yüzde 30'u ikinci kuşağa, yüzde 12'si üçüncü kuşağa geçebiliyor. Dördüncü kuşağa geçebilenlerin oranı ise yüzde 3'te kalıyor" (Sabancı, 2017). Bu durum çekirdek aile bazında devam ettirilebilen bir kısım birlikteliklerin, ailenin geniş aile hüviyetini aldıktan sonra devam ettirilemediğini ortaya koymaktadır. Fakat her halükarda çeşitli düzeylerde yapılan araştırmalarda ailenin güçlü bir sosyal sermaye rezervi oluşturduğu da görülmektedir. İlaveten burada belirtmek gerekir ki, sadece Türkiye'de değil güvenin olmadığı birçok toplumda ekonomik örgütler aile şirketi olarak kullanılmaktadır (Karagül-Masca, 2005, s. 41-42). Güvenin olmadığı toplumlarda bireyler, dişardaki insanlarla kurulması muhtemel ortaklıklar için çekimser kalmakta ve şayet bir ekonomik ortaklık kurulacaksa, bunun aile üyelerinden birileri olması gerektiği noktasında tavır takınmaktadırlar. Çünkü güven aileden, aile sosyal sermayeden ve sosyal sermaye de ekonomiden müstakil düşünülemeyecek kadar birbirine bağlıdır. Nihai olarak sosyal sermayenin iktisadi bir kavram oluşu (Taştan, 2015, s. 17), aile kurumunun ve aile ilişkilerinin de iktisadi yönünü ortaya koymaktadır.

Esnafların aileleri vasıtasıyla edindiği sosyal sermayenin onlara pratikte bir dizi başka faydaları da vardır. Bu noktada ekonomik kriz zamanlarında aile üyelerinden finansal 
destek alınması, işgücünün yetersiz kalması durumunda aileden takviye işgücü sağlanması (Kabadayı, 2015, s. 15), mekân bazlı problemlerin aile üyelerinin mülkiyeti vasıtasıyla aşılması ve en önemlisi de psişik sorunların çözümü için ilk olarak aile üyelerinden destek alınması başlıca faydalardandır. Bunun yanında kişiden kişiye ve aileden aileye değişen bu yoğun dayanışma tutumları akrabalar için de geçerlidir. Çemberin genişlemesi mütekabiliyet meselesini daha fazla devreye sokar iken akrabalar da yine belirli oranda esnaflar için bir sosyal sermaye parametresini oluşturmaktadır. Aileden görülen desteğin akrabalardan da belirli oranda görülebilmesi Türkiye'deki esnaf profilinin geleneksel dayanışmacı kodlarını -en azından kurumsallaşmış işletmeler nispetinde- daha fazla koruduğunu göstermektedir. Bu durum özellikle Batı dünyasındaki sosyal sermaye rezervlerinin Türkiye'deki rezervlere göre farklı bir yapısal hüviyetinin olduğunun anlaşılması açısından önemlidir. Nitekim formel ve informel ağlar üzerinden ölçülen rezervlerin kendi içerisinde de ayrışmış olması, aile ile akrabanın, devlet ile derneğin yapısal özellikleri itibariyle farklı düzeyde güven, mütekabiliyet ve ilişki biçimlerini içermesi, hem ülkeler bazında hem de kişiler bazında sosyal sermaye göstergelerinin yeniden gözden geçirilmesini gerektirmektedir.

Esnafların aile ve akraba dışında informel olarak düşünülebilecek, sonraki ilişki halkalarını arkadaşlar, komuşular ve yakın çevre olarak nitelendirilebilecek kişiler oluşturmaktadır. Bu noktada esnafın muhatap olduğu kişilerle geliştirdiği ilişkilerin niteliği ve niceliği onun dayanışma ağlarını belirlemesinin yanında sosyal sermayesi hakkında da ipucu vermektedir. Esnaflar özellikle işyerindeki komşularıyla güçlü bir dayanışma içerisinde olabilmekte, hem ekonomik açıdan hem de esnaflığın niteliğinin öğrenilmesi açısından komşuları ile ilişkiler geliştirebilmektedir. Fakat esnaflar açısında burada da yine içsel ve dışsal değişkenlerin önemi ortaya çıkmaktadır. Mesela kendisiyle aynı işi yapan ya da aynı malı satan bir esnaf, rekabet ettiği komuşusu ile kurduğu ilişki biçimini mesafeli bir zemin üzerinden inşa edebilirken, boş zamanlarında birbirlerini sıklıkla ziyaret eden hatta eşler ve çocuklar arasındaki bağlantıları kurmaya önem veren esnafların kendi arasında geliştirdiği ağlar, ilişkiler ve sermaye rezervleri değişkenlik arz edebilemektedir.

Esnaflar girdiği bu ilişkiler vasıtasıyla esnaflığı nasıl yapması gerektiğinden, olağanüstü zamanlarda hangi becerileri devreye sokması gerektiğine kadar birçok pratiği kurumsallaştırmakta ve sürekli olarak sermaye rezervini çoğaltmaktadır. Bu durum yaşlı esnaf ile genç esnaf arasındaki tecrübe-sermaye oranlarını da belirleyebilmektedir. Esasında esnaflar sürekli olarak biriktirmiş olduğu sosyal sermayenin birgün kullanılabileceğinin farkında olmakla berebar mutlak bir rasyonel eylem metodolojisi ile bu ilişkileri kurmamakta ve ahlak, din, kültür vs. gibi normatif hususiyet bildiren fenomenlerin etkisi ile bir dayanışma içerisine girebilmektedir. Ancak ilişki hangi amaçla kurulursa kurulsun nihai olarak esnafın psiko-sosyal olarak gelişimine veya görebileceği zararların en aza indirgenmesine hizmet etmektedir. Fakat tüm bunlara rağmen kolektif bilinç ve sosyal sermayenin olağanüstü zamanlarda daha fazla görünür olduğu düşünüldüğünde, esnafların sermayesi içerisinde özellikle banka kredilerinin çok olması (Kabadayı, 2015, s. 40) informel nitelikteki sosyal sermaye rezervlerinin kimi yerde yetersiz olduğu anlamına gelebilmektedir. 


\section{ESNAFLARIN SOSYAL SERMAYE REZERVI: KONYA ÖRNEĞİ}

\section{Araştırmanın Metodolojisi}

Çalışma, Türkiye'de modern-kapitalist ekonomik sistem içerisinde geleneksel kodlar üzerinden üretim faaliyetlerini sürdürmeye çalışan bir kısım esnafların yaşam pratikleri göz önünde bulundurularak oluşturulmuştur. Bu noktada özellikle Konya Bedesten Çarşısı'nda terzilik yapan Mustafa Ölmez'in, tek başına çalışmaya ilham kaynağı olduğu söylenebilir. Ölmez ile yapılan bir kısım nitel görüşmelerden sonra görüldü ki, Türkiye'de modern ekonomik göstergelerden ve enstrümanlardan müstakil bir şekilde esnaflık faaliyetini sürdürmeye çalışan önemli bir kesimin mevcudiyeti söz konusudur. Görüşmeler sırasında Ölmez'in kredi kartı kullanmadığı, müşteriler ile arasındaki ilişkiyi formel prosedürlerden ziyade güven esasına dayalı olarak inşa ettiği, ev iaşesi ve dükkan malzemeleri için küçük cep defterleri tuttuğu, esnaf arkadaşlarına dair ciddi güven göstergelerine sahip olduğu, çalıştırdığı işçinin ücretini ve borçlarını kendi kişisel ihtiyaçlarından önde tuttuğu anlaşılmıştır. Detaylara inildiğinde bu gibi hususiyetlerin Ölmez'i, mevcut ekonomik sistemin dönüştürücü etkilerine karşı direnç ve mukavemet sahibi kıldığı da görülmüştür. Birçok açıdan insan ilişkilerinin doğasındaki dönüşümün aksine Ölmez, ekonomik sistemin değer sisteminden bağımsız bir şekilde düşünülemeyeceğini göstermiştir. Ölmez ile beraber toplamda 3 kişi ile gerçekleştirilen nitel görüşmeler araştırmanın ilk omurgasını oluşturmuştur. Böylece araştırmanın sosyal sermaye eksenli temel soruları oluşturulabilmiş, esnaflık fenomeninin ekonomik sermayeden ziyade sosyal sermayesi ile beraber incelenmesi gerektiği kanısı hâsıl olmuştur.

Betimleyici bir desen ile yapılandırılan bu araştırmanın, literatüre olması beklenen özgün katkısı: sosyal sermayesi bağlamında esnaflık fenomeninin incelenmiş olmasıdır. Yukarıda ifade edilen teorik hususlar yeni olan bir bakış açısını ortaya koymasa da sosyal sermaye çalışmalarının esnaflık fenomenine odaklanması gerektiği noktasındaki vurgu, yeni sayılabilecek noktadadır. Dolayısıyla araştırmanın konusu olan sosyal sermayesi bağlamında esnaflık, aynı zamanda araştırmanın önemini de imlemektedir. Araştırma için hipotez/ler oluşturulmamıştır ve açıklamadan ziyade anlamaya yönelik bir çabayı ihtiva etmektedir. Araştırmanın anlamayı hedeflediği en temel husus; "esnafların sosyal sermaye rezervleri ne yoğunluktadır?" sorusunun sorulmasını gerekli kıldı. Bu sorunun anlaşılması için daha önce yapılmış çalışmalar da göz önünde bulundurulduğunda, bir kısım alt soruların sorulma zarureti doğmuştur. Bu noktada çalışmanın soruları şu şekilde siralanabilir:

- Esnaflar sosyal sermaye göstergesi olarak addedilebilecek bir kısım formel ve informel ağlara ne sıklıkla başvurmaktadır?

- Esnaflar iyi bir esnafın yetişmesi için çalışabilecek kurum ve kuruluşların çalışıp çalışmadığına dair nasıl bir kanaate sahiptirler?

- Esnaflar faydalanabilecekleri kurumların faaliyetlerinden ne kadar haberdarlar?

- Esnafların kendi arasındaki güven göstergeleri ne durumdadır?

- Ekonomik kriz zamanlarında formel ve informel ağlara başvurmayı düşünen esnafların oranları ne durumdadır?

Araştırmada oluşturulan sorular ve ölçekler temelde OECD, Dünya Bankası ve Dünya Değerler Araştırması çalışmalarından esinlenerek oluşturulmuştur. Ölçeklerin ve soruların, katılımcıların bilgisine ulaşmak için kendi içerisinde eleştirilen bir kısım eksik tarafları olsa 
da genel olarak bu üç kurumun metodu birçok araştırmaya ilham olmuştur. Özellikle OECD'nin beş düzeyde sosyal sermayeyi ölçtüğü görülmektedir. Bunlar:

1- Yurttaşlık katılımı ile oy kullanma ve eylem pratikleri ölçülmekte,

2- Sosyal ağlar ve destek ile katılımının çevresindeki ilişkilerin mahiyeti ölçülmekte,

3- Sosyal katılma ile gönüllü organizasyonlarda yer alıp almadığı ölçülmekte

4- Karşılıklı güven ile genel güven düzeyleri ölçülmekte

5- Sosyal çevre soruşturması ile çevre hakkındaki düşünceler ölçülmektedir (Aydemir, 2011, s. 103).

Yukarıdaki birinci madde haricindeki diğer maddelerden esinlenerek bir soru formu oluşturulmuştur. Esnaflık ve sosyal sermaye arasındaki ilişkiyi anlama çabasında olan çalışma, sosyal sermaye rezervine esnaflık parametresinin eklenmesinden dolayı yeniden yapılandırılmış sorulara ve ölçeklere ihtiyaç duymuştur. Bu minvalde OECD, Dünya Değerler Araştırması ve Dünya Bankası'nın soru formları esnaflık eksenine uyarlanmaya çalışılmıştır. İlaveten Konya'da Aydemir (2011), Tecim (2011) ve Aksan'ın (2015) yaptığı sosyal sermaye ve ağ araştırmalarından soru formunu yerelleştirmek için çeşitli düzeylerde faydalanılmıştır. Söz konusu çalışmaların örneklemi ile bu çalışmanın örnekleminin benzerlikler taşıması; bu çalışma ve soru formu için ister istemez mezkûr kurumların çalışmalarının yanında, diğer üç çalışmanın da göz önünde bulundurulmasını gerekli kılmıştır. OECD, Dünya Değerler Araştırması ve Dünya Bankası çalışmalarındaki güven ölçeklerinin Türkiye'de ciddi bir şekilde eleştirilmesi, özellikle güven sorusunun yeniden gözden geçirilmesini zorunlu kılmıştır. "Sizce insanların geneline güvenlir mi?" sorusu yerine "Konya esnafında güven konusunda söyleyeceğim yargılardan hangisi sizin fikrinizi yansıtır?" şeklinde bir soru oluşturulmuştur. Böylece katılımcıların, "insanların geneline" terkibindeki ötekileştirme imasından nispeten kurtulması hedeflenmiştir.

Araştırma Konya kent merkezi ile sınırlandırılmış ve toplamda 450 esnafa anket formu uygulanmıştır. Çalışmada, özellikle esnaf ağlarının formel nitelikte kurumsallaşmış şekli olarak işaret edilen esnaf odaları dikkate alınmış ve odalara dair verileri sunmak için gayret edilmiştir. Çalışmanın sınanabilirliği daha önceki çalışmaların olmamasından dolayı şimdilik imkân dâhilinde görünmemektedir. Ancak özellikle OECD, Dünya Değerler Araştırması ve Dünya Bankası verileri açısından, ölçekten kaynaklanan farklılıklar vurgulanabilecek niteliktedir. 3 nitel görüşmeden sonra, 50 kişi ile yapılan pilot uygulama soru formunun son halini almasını sağlamıştır. Pilot uygulamada görüldü ki esnaflar formel olarak daha çok esnaf odaları, mesleki dernek ve vakıflar, mesleki olmayan dernek ve vakıflar ve devlet kurumlarından bir şeylerin yapılması için beklenti içerisindedirler. Nitekim ilişkilerin görece yoğunluklu olarak kurulduğu kurumlar da bu kurumlardır. Esnaflar informel olarak nitelendirilebilecek ağlarda ise dini guruplar ve dernekler, esnaf arkadaşlar ve aile gibi birincil ilişkilerin yoğunlukta olduğu gurupların-kurumların ismini öne çıkarmıştır. Pilot uygulama sonucunda soru formu tekrardan yapılandırılarak bir kısım sorular çıkarılmış, ağ seçenekleri pilot uygulamaya göre yeniden yapılandırılmıştır. $\mathrm{Bu}$ noktada esnafların sosyal sermaye rezervleri sınırlı bir kısım formel ve informel ağlar üzerinden anlaşılmaya çalışılmıştır. Öte yandan bu başlıkların zorunlu bir şekilde azaltılması, sosyal sermaye rezervlerini bütün olarak ortaya koymanın önünde bir sınırlılık olarak karşımıza çıkmaktadır. Dolayısıyla burada nicel araştırmanın doğasından kaynaklanan bir kısım zorluklar, bu araştırmanın temel sınırlılığı olarak görülebilir. 
Araştırmanın diğer sınırlılığı ise TESK'e göre Konya çapında bulunan 51.134 esnafın hangi ilçelerde sektörel olarak ne yoğunlukla öbekleştiğinin saptamasının yapılamamasından kaynaklanmaktadır. Ancak bunun yanında KONESOB başkanı, yaklaşık 55.000 esnafın 5.379'unun yani \% 9,78'inin kadın olduğunu ifade etmektedir. 450 kişi ile yapılan görüşmeden \%15,1'inin kadın olması bu açıdan bir benzerlik olarak varsayılabilir.

\section{Araştırmanın Bulguları}

Konya'nın merkez ilçelerinde gerçekleştirilen çalışmaya toplamda 450 esnaf görüşmeci olarak katılmıştır. Katılımcılardan 68 kişi $(\% 15,1)$ kadın, 382 kişi $(\% 84,9)$ erkektir. 450 kişi arasında 352 kişi $(\% 78,2)$ evli, 83 kişi $(\% 18,4)$ bekâr, 10 kişi $(\% 2,2)$ boşanmış, 5 kişinin de $(\% 1,1)$ de eşi ölmüştür. 18-25 yaş arasında 53 kişi $(\% 11,8)$, 26-35 yaş arasında 139 kişi (\%30,9), 36-50 arasında 182 kişi (\%40,4), 51-65 yaş arasında 67 kişi $(\% 14,9)$, 66 yaş ve üzeri de 9 kişi (\%2) katılımcıların yaş aralığını teşkil etmiştir. Katılımcıların yaş ortalaması 39,264 iken, standart sapması 11,611'dir. En düşük yaş 19 en yüksek yaş 84'tür. Katılımcıların esnaflık yaptığı ilçelere göre dağılımı 260 kişi $(\% 57,8)$ Selçuklu, 136 kişi $(\% 30,2)$ Meram, 54 kişi (\%12) Karatay şeklinde olmuştur. İlaveten 65 kişi $(\% 14,4)$ Konyalı değil iken, 385'i $(\% 85,6)$ Konyalıdır. Aylık gelirini söyleyen 427 kişi $(\% 94,9)$ olmuştur ve geçerli katılımcıların içerisinde 1-1600 tl arasında 61 kişi (\%13,6), 1601-2500 tl arasında 71 kişi (\%15,8), 2501-4000 tl arasında 94 kişi (\%20,8), 4001-6000 tl arasında 78 kişi (\%17,3), 6001-9000 tl arasında 23 kişi $(\% 5,1), 9001$ tl ve üzerinde de 100 kişi $(\% 22,2)$ bulunmaktadır. Geçerli katılımcıların aylık gelir ortalaması 9,883 tl, standart sapması ise 22,423 tl'dir. En düşük gelir $40 \mathrm{tl}$ iken, en yüksek gelir 100.000 tl'dir. Bu gelir ortalaması küçük esnaf olarak tarif edilen işletme sahiplerinden ziyade orta ölçekli esnaf nitelemesine daha fazla uymaktadır. Katılımcılardan 109 kişi $(\% 24,2)$ haricen geliriniz var mıdır? sorusuna "evet" şeklinde cevap vermiş ve katılımcılar arasından 62 kişi $(\% 13,8)$ 1-1600 tl arasında, 25 kişi $(\% 5,6)$ 1601-2500 tl arasında, 22 kişi de $(\% 4,9) 2500$ tl üzerinde "ek gelirim var" demiştir. Ek geliri olanların ortalaması 2,424 tl, standart sapması da 3434 tl'dir. En düşük ek gelir 100 tl en yüksek ek gelir ise 30.000 tl'dir. Katılımcılardan 17 kişi $(\% 3,8)$ mezun değil ancak okuryazar, 184 kişi $(\% 40,9)$ ilkokul mezunu, 155 kişi $(\% 34,4)$ lise mezunu, 81 kişi (\%18) üniveriste mezunu, 13 kişi de $(\% 2,9)$ yüksek lisans veya doktoradan mezun olmuştur. Geçerli katılımclardan 220 kişi $(\% 50,1)$ 1-3 arasında, 205 kişi $(\% 46,7)$ 4-7 arasında, 14 kişi $(\% 3,2) 8$ ve üzeri bireye bakmakla yükümlü olduğunu söylemiş̧tir. Katılımcıların bakmakla yükümlü olduğu birey sayısının ortalaması 3,58'dir. İşçi çalıştıranların 296'sı (\%82,2) 1-3 arası, 51'i (\%14,2) 4-7 arası, 13'ü de (\%3,6) 8 ve üzeri işçi çalıştırmaktadır. Katılımcıların "Esnaflığı kimden öğrendiniz?" sorusuna vermiş oldukları cevap: 153 kişi (\%34) aileden, 146 kişi $(\% 32,4)$ ustadan, 5 kişi $(\% 1,1)$ liseden, 3 kişi $(\% 0,7)$ üniversiteden, 7 kişi $(\% 1,6)$ özel kurslardan, 133 kişi $(\% 29,6)$ kendi kendime, 3 kişi de $(\% 0,7)$ diğer şeklindedir. Katılımclardan 105 kişi (\%23,3) 0-5 yıl, 155 kişi (\%25,6) 6-12 yıl, 110 kişi $(\% 24,4)$ 13-20 yıl, 21 kişi $(\% 26,6) 21$ ve üzeri yıl kadar esnaflık yaptıklarını beyan etmişlerdir. Katılımcıların ortalama esnaflık yapma süreleri 15,46 yıl iken, standart sapma 11,529 'dur. Katılımcilar arasında en az 1, en fazla 58 yıllık esnaf vardır. Katılımciların içinden $334^{\prime}$ ü $(\% 74,2)$ işyerinin kira olduğunu, 116 'sı da $(25,8)$ işyeri mülkiyetinin kendilerine ait olduğunu beyan etmiştir. 


\section{Esnafların Formel ve İnformel Ağlarla Olan İlişkisi}

Tablo 1. Söyleyeceğim kurum ve kuruluşları ziyaret etme sıklığınız nedir? Sık sık ziyaret ederim, arada ziyaret ederim, hiç ziyaret etmem şeklinde cevaplayınız.

\begin{tabular}{|l|c|c|c|c|}
\hline (\%) & Sık sık & Arada & Hiç & Toplam \\
\hline Esnaf odaları & 7,1 & 27,6 & 65,3 & 100 \\
\hline Mesleki dernekler ve vakıflar & 3,6 & 15,7 & 80,7 & 100 \\
\hline Dini gurup ve Cemaatler & 4,9 & 14,7 & 80,4 & 100 \\
\hline Esnaf kahvesi-lokali & 4,4 & 6,9 & 88,7 & 100 \\
\hline
\end{tabular}

Tablo 1 incelendiğinde katılımcıların \%65,3'ünün esnaf odalarını, \%80,7'sinin mesleki dernek ve vakıfları, \%80,4'ünün dini guruplar ve vakıfları, \%88,7'sinin de esnaf kahvesini veya lokalini hiç ziyaret etmediği görülmektedir. Rekabet şartlarını düzenleyen ve gerektiğinde esnaflara eğitim, seminer ve destek veren dernekler, vakıflar ya da odalar bu noktada esnaflar tarafından hayati bir kurum olarak görülmemektedir. Nitekim rakamlar da bunu destekler niteliktedir. Öte yandan formel veya informel olarak teşkilatlanmış olan bazı "mesleki dernekler ve vakıflar"a da benzer bir tutum içerisinde bulunan esnaflar, bu kurumlara da çok fazla gitmemektedirler. Ancak her esnaf uğrayabileceği bir vakıf veya dernek de bulamayabilmektedir. Kendi içerisinde dernekleşme faliyeti gösteren mesleklerin sayısının az olması, bu soruyu her katılımcı için anlamlı kılmamaktadır. Dini guruplar ve vakıflara olan uğrama sıklığı ise kişinin içinde bulunduğu psiko-sosyal gerçeklik ile yakın bir ilişki içerisindedir. Son seçenek olan esnaf kahvesi veya lokaline uğrama sıklığı katılımcıların işletmelerine yakın bir kahvenin-lokalin bulunup bulunmadığı ile ilgilidir. $\mathrm{Bu}$ noktada işyerinin yakınında bir kahve veya lokal bulunmayan kişilerin bu soruya vermiş oldukları cevap genelde olumsuzdur. Yanında herhangi bir eleman çalıştırmayan esnaflar da yine kahveye veya lokale uğramak noktasında oldukça nadir girişimlerde bulunmaktadır. Tüm bu rakamlar ve uğrama sıklıkları esnafların sosyal sermayesine dair net rakamlar vermese de en azından esnafların kendi içerisindeki organizasyonlara olan teveccühünü göstermeye dair makul rakamlar olarak görülebilir. Bunun yanında söz konusu kurumların mekânlarına uğrayanlar üzerinden ayrıca analizler yapılabilir. Nihai olarak bu seçenekler esnafların en fazla gitme sıklığı gösterdiği kurumları içermesine rağmen oldukça düşük rakamlar suretinde karşımıza çıkmaktadır. Buradaki uğrama sıklıklarının büyük oranda az olması, genel tablo açısından oldukça anlamlıdır. Bu tablo, esnafların kendi arasında inşa ettikleri birlikteliklerin formel düzeyde yüksek olmadığını göstermektedir. 
Tablo 2. Size göre iyi bir esnafın yetişmesi için doğrudan ya da dolaylı olarak fayda edebilecek kurum ve kuruluşlar çalışıyorlar mı? Çalışıyor, çalışmıyor ya da kararsızım şeklinde cevaplayınız.

\begin{tabular}{|l|c|c|c|c|}
\hline$(\%)$ & Çalışıyor & Çalışmıyor & Kararsızım & Toplam \\
\hline Esnaf Odaları & 21,1 & 66 & 12,9 & 100 \\
\hline Mesleki Dernekler ve Vakıflar & 12 & 70,7 & 17,3 & 100 \\
\hline Dini Gurup ve Cemaatler & 10,9 & 66,7 & 22,4 & 100 \\
\hline Devlet Kurumları & 29,1 & 52,9 & 18 & 100 \\
\hline Mesleki Eğitim kursları & 28,7 & 52,9 & 18,4 & 100 \\
\hline Yerel ve ulusal basın & 11,8 & 67,5 & 20,7 & 100 \\
\hline
\end{tabular}

Tablo 1'de esnafların kurumsallaşmış dernek vakıf ve odalara karşı olan tutumlarına dair tedrici rakamlar ortaya çıkar iken tablo 2 esnafların söz konusu kurumlara verdikleri notu göstermektedir. Esnaflar \%66 ile esnaf odaları için, \%70,7 ile dernek ve vakıflar için, $\% 66,7$ ile dini grup ve cemaatler için, \%52,9 ile devlet kurumları için, 52,9 ile mesleki eğitim kursları için, \%67,5 ile de yerel ve ulusal basın için "çalışmıyorlar" şeklinde kanaat belirtmişlerdir. Rakamlar arasında söz konusu kurum ve kuruluşlardan en fazla devlet kurumları için "çalışıyor" şeklinde kanaat belirten esnaflar, dernekler ve vakıfların çalışmadığına dair en belirgin kanaati taşımaktadır. Burada dernekler ve vakıflar seçeneği ile dini gurup ve cemaatler seçeneğinin ayrı ayrı sorulma ihtiyacı ise cemaatlerin teolojik mahiyetinden kaynaklanmıştır. Bu tablo, esnafların kendileri ile ilgili kurumsallaşmış yapılara olan teveccühünü göstermesi açısından oldukça önemlidir.

Tablo 3. Esnaf odalarını ziyaret etme sıklığına göre odaların çalışıp çalışmadığına verilen cevaplar

\begin{tabular}{|l|c|c|c|}
\hline Esnaf Odaları & Sık Sık (\%) & Arada (\%) & Hiç (\%) \\
\hline Çalışıyor & 68,8 & 33,1 & 10,9 \\
\hline Çalışmıyor & 18,8 & 54 & 76,2 \\
\hline Kararsızım & 12,5 & 12,9 & 12,9 \\
\hline Toplam & $\mathbf{1 0 0}$ & $\mathbf{1 0 0}$ & $\mathbf{1 0 0}$ \\
\hline
\end{tabular}

Yukarıdaki çapraz tablo (Tablo 3) oldukça manidar rakamlar ortaya koymaktadır. Buna göre esnaf odalarını sık sık ziyaret edenlerin $\% 68,8$ 'i odaların çalıştığını ifade ederken; odaları hiç ziyaret etmeyenler \%76,2 oranında odaların çalışmadığına dair kanaat belirtmektedirler. Yani odaları ziyaret etme durumu ile onların çalışıp çalışmadığına dair kanaat belirtme arasında bir ilişki söz konusudur. Burada iki yorum yapılabilir. Birincisi odaları sık sık ziyaret edenler orada odaların çalıştığını kendi gözleri ile görmektedirler ve buna göre kanaat belirtmişlerdir. İkincisi odaları ziyaret etmeyenler odaların çalışmadığına dair zaten bir kanaate -belki de önyargıya- sahip oldukları için odaları ziyaret etmemektedirler. Çünkü odaları arada bir ziyaret ettiğini ifade edenler de odaların \%54 gibi bir rakamla çalışmadığına hükmetmişlerdir. 
Tablo 4. Mesleki dernek ve vakıfları ziyaret etme sıklığına göre, onların çalışıp çalışmadığına verilen cevaplar

\begin{tabular}{|l|c|c|c|}
\hline Mesleki Dernek ve Vakıflar & Sık S1k (\%) & Arada (\%) & Hiç (\%) \\
\hline Çalıșıyor & 37,5 & 28,2 & 7,7 \\
\hline Çalışmıyor & 56,3 & 50,7 & 75,2 \\
\hline Kararsızım & 6,3 & 21,1 & 17,1 \\
\hline Toplam & $\mathbf{1 0 0}$ & $\mathbf{1 0 0}$ & $\mathbf{1 0 0}$ \\
\hline
\end{tabular}

Tablo 3'e benzer bir oran da tablo 4'te yakalanmıştır. Buna göre mesleki dernek ve vakıfları sık sık ziyaret edenler, mesleki dernek ve vakıfların en fazla çalıştı̆̆ını ifade edenlerdir. Yine aynı korelasyona göre hiç ziyaret etmeyenler, en fazla çalışmadığını iddia etmektedirler. Fakat tablo 3'ten farklı olarak burada mesleki dernek ve vakıfları sık sık ziyaret edip onların faaliyetlerini gördüğü halde onların çalışmadığını ifade eden \%56,3’lük bir kesim var ki burada dikkat çekicidir.

Tablo 5. Dini grup ve cemaatleri ziyaret etme sıklığına göre onların çalışıp çalışmadığına verilen cevap

\begin{tabular}{|l|c|c|c|}
\hline Dini gurup ve cemaatler & S1k Sık (\%) & Arada (\%) & Hiç (\%) \\
\hline Çalıșıyor & 36,4 & 24,2 & 6,9 \\
\hline Çalıșmıyor & 31,8 & 51,5 & 71,5 \\
\hline Kararsızım & 31,8 & 24,2 & 21,5 \\
\hline Toplam & $\mathbf{1 0 0}$ & $\mathbf{1 0 0}$ & $\mathbf{1 0 0}$ \\
\hline
\end{tabular}

Tablo 5 diğer iki tablo ile büyük oranda benzerlikler taşımaktadır. Dini grup ve cemaatleri sık sık ziyaret edenler; esnafların doğrudan ya da dolaylı gelişimi için (ki burada deneğin zihninde manevi gelişimin canlanması için dolaylı vurgusu da yapılmıştır) \%36,4 ile en fazla, çalıştığını ifade eden küme içerisindedir. Yine söz konusu gurupları hiç ziyaret etmeyenler de \%71,5 ile en fazla çalışmadığını ifade eden gurubu oluşturmaktadırlar. Fakat burada dikkat çekici husus kararsızların oranıla ilgilidir. Kurum ve kuruluşları sık sık ziyaret eden esnafların kararsız olma oranları tablo 3 ve tablo 4'e göre burada artmaktadır. Sık sık ziyaret etme ile çalışıp çalışmadığına karar verebilme arasında, diğer iki çapraz tabloda doğru orantı var iken; burada esnaflar dini gurup ve cemaatleri sık sık ziyaret ettiklerini bildirmelerine rağmen, onların çalışıp çalışmadığına $\% 38,8$ gibi bir rakam ile karar verememişlerdir. Buradan iki yorum yapılabilir. İlk olarak denekler dini gurup ve cemaatlerin esnaflara dönük nasıl çalışabileceklerini -manevi gelişimi göz ardı ederekalgılayamamış olabilirler. İkinci olarak da dini gurup ve cemaatler, en azından esnaf odaları ya da mesleki dernekler ve vakıflar gibi aidiyet duygusunun daha az geliştiği yerler olmadığından dolayı kişiler, dini grup ve cemaatlere bir aidiyet duymakta ve onların çalışamadığını söylemekten imtina etmektedirler. Dolayısıyla bu aidiyet duygusu kişileri olumsuz bir kanaat belirtmekten men etmiş olabilir. 
Tablo 6. Söyleyeceğim kurum ve kuruluşların esnaflara yönelik faliyetlerinden haberdar mısınız? Haberdarım, kısmen haberdarım, haberdar değilim şeklinde cevaplayınız.

\begin{tabular}{|l|c|c|c|c|}
\hline $\mathbf{( \% )}$ & Haberdarım & Kısmen & Haberdar & Geçerli Sayı \\
\hline Esnaf odaları & 38,5 & 22,3 & 39,2 & $\mathbf{4 4 9}$ \\
\hline Devlet kurumları & 32,1 & 27,6 & 40,3 & $\mathbf{4 4 9}$ \\
\hline KOSGEB & 31,3 & 20,2 & 48,5 & $\mathbf{4 3 1}$ \\
\hline Kredi olanakları & 28,6 & 19,5 & 51,9 & $\mathbf{4 4 7}$ \\
\hline Ticaret odası & 27,4 & 19 & 53,6 & $\mathbf{4 3 1}$ \\
\hline Kanun yönetmelik vs. & 24,9 & 26,1 & 49 & $\mathbf{4 4 5}$ \\
\hline Hibe olanakları & 21,3 & 18,6 & 60,1 & $\mathbf{4 4 6}$ \\
\hline Esnaf kooparatifleri & 19,4 & 22,7 & 57,9 & $\mathbf{4 4 9}$ \\
\hline Ajanslar & 16,4 & 17,9 & 65,7 & $\mathbf{4 4 6}$ \\
\hline
\end{tabular}

Tablo 6'daki rakamlar dikkate alındığında esnaflar en fazla ajans faaliyetleri için $\% 65,7$ ile haberdar değilim kanaatini belirtirler iken; en fazla da esnaf odalarının faaliyetlerinden 38,5 ile haberdar olduğunu ifade etmektedirler. Tablo 1'de esnaf odalarını sık sık veya arada bir ziyaret ettiğini belirtenlerin oranının \%34,7 olması; esnafların çoğunluğunun esnaf odaları ile bağının olmadığını gösterirken burada (tablo 6) esnafların $\% 60,8$ 'inin oda faaliyetlerinden haberdar olduğunu belirtmesi üzerinde durulması gereken bir husustur. Burada sorulması gereken soru: esnaflar, odaları ziyaret etmemelerine rağmen nasıl oda faaliyetlerinden haberdar olabilirler? Muhtemeldir ki odalar, esnaflar için aracı bir takım mekanizmaları çalıştırarak esnafları bilgi sahibi kılmaktadırlar. Bu durum esnaf odalarının en azından mevcut organizasyonlara yönelik bilgileri esnaflarla paylaştığını göstermektedir. Ancak nihai olarak tablo 6'daki rakamlar, birçok başlıkta esnafların kendilerine yönelik kurum, kuruluş ve faaliyetlerden yarı yarıya haberdar olmadıklarını göstermektedir. Bu durum öncelikli olarak esnafların bu fenomenlere ilgi duymaması ile açıklanabilecek nitelikteyken, söz konusu kurumların ve faaliyetlerin esnaflara neleri vadettiği de önemli bir sorun alanı olarak karşımıza çıkmaktadır. Bu çalışmanın teması açısından esnaflar, kurumsal yapılar ile -bir sosyal sermaye göstergesi olduğu göz önüne alındığında- sürekli ve yoğunluklu bir ilişkiye genel olarak girmemektedirler. Araştırma örnekleminin Konya kent merkezini teşkil etmesi ve ortalama gelirin yüksek olması göz önüne alındığında, buradaki esnafların genel kurumsal yapılarla olan ilişkisinin daha yoğunluklu olmasını gerektirmektedir. Kırsal kesimdeki küçük esnaflar veya aylık ortalama geliri düşük olan esnafların kurumsal yapılarla olan ilişkisi buradaki rakamlardan çok daha düşük rakamları ihtiva edecektir. Çünkü araştırma sürecinde küçük esnafın kredi, hibe, eğitim ya da esnaflıkla ilgili kurum ve kuruluşlara dair daha mesafeli olduğu gözlemlenmiş; tamamen dar ölçekte mekânlar ve sosyal çevreler ile esnaflık faaliyetlerini sürdürmeye çalıştı̆̆ görülmüştür. 


\section{Esnafların Kendi Arasındaki İlişki ve Güven Göstergeleri}

Tablo 7. Son bir yılda esnaflar arasında düzenlenmiş piknik, gezi, yemek gibi sosyal etkinlikleriniz oldu mu? Olduysa kaç kere birlikte oldunuz?

\begin{tabular}{|l|c|c|}
\hline & Sayı & Yüzde \\
\hline Oldu & 92 & 20,4 \\
\hline Olmadı & 358 & 79,6 \\
\hline Toplam & $\mathbf{4 5 0}$ & $\mathbf{1 0 0}$ \\
\hline
\end{tabular}

Oldu diyenlerin ortalaması

\begin{tabular}{|l|c|}
\hline Ortalama & 3,62 \\
\hline St. Sapma & 3,871 \\
\hline Min. Sayı & 1 \\
\hline Max. Sayı & 20 \\
\hline Toplam & $\mathbf{9 2}$ \\
\hline
\end{tabular}

Esnafların kendi arasındaki etkileşimine dair ipucu sağlayan önemli göstergelerden bir tanesi de birlikteliğin kurumsallaştığı organizasyonlardır. Bu noktada piknik, gezi ve yemek gibi organizasyonlar önemli bir sosyal sermaye göstergesi olarak okunabilir. Esnafların \%20,4'ü esnaf arkadaşları ile bir organizasyon içinde bulunduklarını beyan ederler iken, \%79,6'sı bir organizasyon içerisinde olmadıklarını ifade etmişlerdir. Oldu diyenlerin ortalamasının standart sapmasının yüksek çıkması önemli bir unsur olarak karşımıza çıkmaktadır. Esnafların sadece \%20,4'lük bir kısmı söz konusu organizasyonlara katılsa da, katılanların çok fazla kez birlikte olduğu ve bazı esnafların bunu bir tutum haline getirme eğilimi taşıdığı görülmektedir.

Tablo 8. Esnaf komşu ilişkileri

\begin{tabular}{|l|c|c|}
\hline Yargılar & Ortalama & Std. Sapma \\
\hline Esnaf komşusuna müşteri gönderir & 3,23 & 1,350 \\
\hline Benimle aynı malı satmaya başlayan komşu ile ilişkim zayıflar & 3,50 & 1,235 \\
\hline Esnaf komşuları ile iş dışında buluşmalar gerçekleştirir & 3,74 & 1,236 \\
\hline Esnaf komşusunun ailevi problemleri ile de ilgilenir & 4,08 & 1,079 \\
\hline Esnaflar komşularının düğün ve cenaze törenine katılır & 4,10 & 2,639 \\
\hline Esnaf dükkânını komşusuna emanet eder & 4,12 & 1,023 \\
\hline Esnaf komşularına yardım eder & 4,14 & 2,214 \\
\hline Küs olan komşularımı barıştırmaya çalışırım & 4,14 & 2,161 \\
\hline
\end{tabular}

Tablo 8'de esnafların komşuluk olgusuna nasıl yaklaştıkları bir kısım yargılar üzerinden anlaşılmaya çalışılmıştır. İfadeye katılım oranları 1'den (kesinlikle katılmıyorum) 5'e (kesinlikle katıliyorum) kadar olan skala arasında belirlenmiştir. Yukarıda tüm 
katılımcıların ortalamasından çıan rakamlarda esnaflar, idealize edilmiş değer yargılarına katılıp katılmadığını ifade etmiştir. Yani ortalamaların yüksek çıkması esnafların söz konusu faaliyetleri yaptığını göstermemektedir. Rakamlar esnafların düşünce düzeyinde bu faaliyetlerin makuliyetine nasıl yaklaştığını göstermektedir. Yargıların hem doğrudan esnafın tutumunu öğrenmeye yönelik olması hem de ideal olanın sorulmuş olması ciddi bir farklılık göstermemiş ve yargıların geneli yüksek çıkmıştır. Ancak rekabet ile ilgili olan yargının diğerlerine nispetle düşük çıkması ilgi gösterilmesi gereken bir husustur. Katılımcılar "esnaf komşusuna müşteri gönderir" $(3,23)$ yargısına diğer yargılara nispetle daha az katılmışlardır. Öte yandan "benimle aynı malı satmaya başlayan komşumla ilişkilerim zayıflar" $(3,50)$ yargısının da o nispetle çok yüksek çıkmaması rekabet edimlerinin ilişkileri ciddi bir şekilde tahrip etmeyeceğini de göstermektedir. Öte yandan bu yarg1 -son yargıda olduğu gibi- idealize edilmiş bir yargı değil, doğrudan katılımcının tavrını ölçmeye yönelik bir yargıdır. Burada dikkat çekici diğer yargı ise "esnaf komşuları ile iş dışında buluşmalar gerçekleştirir" $(3,74)$ şeklinde idealize edilerek sorulan yargıdır. Tablo 7'ye göre son bir yılda esnaflar arasında düzenlenmiş piknik, gezi, yemek gibi sosyal etkinlikleriniz oldu mu sorusuna sadece \%20,4'ü oldu şeklinde cevap verir iken; iş dışında buluşma yargısının ortalamasının 3,74 çıkması, esnafların idealize ettikleri tutum ile gerçekleştirdikleri tutum arasındaki farkı ortaya koymaktadır. Öte yandan diğer tutum/yargı sorularının da yüksek olması gösteriyor ki, esnaflar ideal olarak birbirine güvenmek ve birbirleri ile ilişki kurmak gerektiği noktasında oldukça olumlu kanaatlere sahiptirler.

Tablo 9. Konya esnafı için güven konusunda söyleyeceğim yargılardan hangisi sizin fikrinizi yansitır?

\begin{tabular}{|l|c|c|}
\hline & Sayı & Yüzde \\
\hline Konya'da güvenilir esnafların çoğu güvenilirdir & 109 & 24,2 \\
\hline Konya'da güvenilir esnaf vardır & 244 & 54,2 \\
\hline Konya esnafları için dikkatli olmak gerekir & 84 & 18,7 \\
\hline Konya'da güvenilir esnaf yoktur & 13 & 2,9 \\
\hline Toplam & $\mathbf{4 5 0}$ & $\mathbf{1 0 0 , 0}$ \\
\hline
\end{tabular}

Sosyal sermaye için güven ölçeği olarak bilinen ölçeğin yeniden yapılandırılması güven sonuçlarını değiştirmiştir. "Sizce insanların geneline güvenilir mi?" sorusu, "Konya esnafında güven konusunda söyleyeceğim yargılardan hangisi sizin fikrinizi yansıtır?" şeklinde değiştirildi. Şüphesiz bu değişimin sebebi güven göstergelerinin abartılmış bir versiyonunu göstermek değildi. Ancak 30 yıla yakın süredir yapılan araştırmalarda özellikle Dünya Değerler Araştırması'ında- güven göstergelerinin çoğu zaman \%10'nun altında kalması (Aslan, 2016, s. 191) güven ölçeğinin yeniden sorgulanmasını gerektiriyordu. Çünkü birbirine karşı bu kadar temkinli olan bir toplumun içerisinde hiçbir düzen unsurunun istikrarı beklenemez. Soru değiştirildiğinde görüldü ki esnaflar nispeten "öteki" imgesinden müstakil düşünüp kendisini de genelin bir parçası olarak gördüğünde, güven oranı çok daha farklı olarak karşımıza çımaktadır. Güven konusunda \%10'larda olan rakamların \%80'lere çıkması genel sosyal sermaye ölçütü olarak algılanamasa da mevcut çalışmaların ve ölçeklerin sorgulanmasını gerektirmektedir. Mesala Aydemir'in (2011) 2011 yılında yaptığı çalışmada Konya'da güven düzeyi 6,4 çıkmıştır. Ancak benzer bir soru 
esnaflara, esnaflar için sorulduğunda toplamda 78,4'lük bir kesim esnaflara (yani kendilerine) güvenilebileceğini ifade etmişlerdir. Sonuç olarak bu rakamlar gösteriyor ki, Türkiye'de güven oranının düşük çıkması büyük oranda öteki imgesi ile alakalıdır.

\section{Ekonomik Kriz Zamanlarında Çözüm Üretme Stratejileri}

Tablo 10. Ekonomik kriz dönemlerinde aşağıdakilerden hangilerini yapmayı düşünürsünüz? Birden fazla seçenek işaretleyebiliriz.

\begin{tabular}{|l|c|c|}
\hline & Sayı & Yüzde \\
\hline Birikimlerimi harcarım & 255 & 56,7 \\
\hline Aileme borçlanırım & 153 & 34 \\
\hline Aileden işgücü yardımı alıım & 133 & 29,6 \\
\hline Daha küçük bir iş düzeni kurarım & 115 & 25,6 \\
\hline Aynı sektörde ek işler yaparım & 73 & 16,2 \\
\hline Başka sektörde ek işler yaparım & 71 & 15,8 \\
\hline Esnaf arkadaşlara borçlanııım & 53 & 11,8 \\
\hline Bankalara borçlanırım & 51 & 11,3 \\
\hline İşyerini kapatırım başka işte çalışırım & 50 & 11,2 \\
\hline İşçi çıkarırım & 49 & 10,9 \\
\hline Devlete borçlanırım & 43 & 9,6 \\
\hline Konya'yı terk ederim & 13 & 2,9 \\
\hline İş yerini kapatıp çalışmam & 13 & 2,9 \\
\hline Dernek ve vakıflara borçlanırım & 7 & 1,6 \\
\hline İntiharı düşünürüm & 3 & 0,7 \\
\hline Diğer & 12 & 2,7 \\
\hline
\end{tabular}

Tablo 10 esnafların sosyal sermaye göstergelerine dair en önemli verileri içerisinde barındıracak niteliktedir. Çünkü burada aile devreye girmektedir. Esnafların kriz zamanlarında yapmayı düşündükleri seçeneklere bakıldığında $\% 56,7^{\prime}$ sinin ilk başta kendi birikimlerini harcayarak çözüm üretme arayışı içerisinde oldukları görülmektedir. Akabinde \%34 ile "aileme borçlanırım" seçeneğinin gelmesi bireylerin en önemli sosyal sermaye rezervini göstermektedir. Bu durum Aydemir ve Tecim'in (2012) Türk toplumunda işaret ettikleri aile kurumunun sosyal sermaye rezervi noktasındaki önemini doğrular niteliktedir. Yine üçüncü olarak "aileden işgücü yardımı alırım" seçeneğinin \%29,6 gibi bir oranla ifade edilmesi aileye olan teveccühün ve güvenin bir göstergesi olarak algılanabilir. Sırayla "daha küçük bir iş düzeni kurarım $(\% 25,6)$ ", "aynı sektörde ek işler yaparım $(16,2)$ ", "başka sektörde ek işler yaparım $(15,8)$ " seçeneklerinin gelmesi ise bireylerin aileden sonra yine kendi çabalarına verdikleri önemi göstermektedir. Kendi çabaları ve ailesinden sonra ise "esnaf arkadaşlara borçlanırım $(11,8)$ " şeklinde bir kanaatin gelmesi, sosyal sermaye rezervlerinde genel olarak birincil ilişkilerin önemini ortaya koymaktadır. Tablo 10'dan 
çıarılabilecek en önemli sonuç; esnaflar, ekonomik kriz zamanlarında kendi çabaları ve aile yardımı yetmez ise formel kurumlara başvurma eğilimini taşımaktadırlar.

Tablo 11. Kriz zamanlarında "aileden işgücü yardımı almayı düşünürüm" diyenlerin, ailede "bakmakla yükümlü" olduğu kişi sayısına oranı

\begin{tabular}{|l|c|c|c|}
\hline Kaç kişiye bakmakla yükümlü & Sayı & Yüzde & Genel Yüzde \\
\hline 3 ve altı sayıya bakmakla sorumlu olanlar & 58 & 44,3 & 51,1 \\
\hline 4 ve üzeri sayıya bakmakla sorumlu olanlar & 73 & 55,7 & 48,9 \\
\hline Toplam & $\mathbf{1 3 1}$ & $\mathbf{1 0 0}$ & $\mathbf{1 0 0}$ \\
\hline
\end{tabular}

Katılımcıların genelinin arasında 3 ve onun altında kişiye bakmakla sorumlu olanlar $\% 51,1$ iken, 4 ve onun üzeri sayıya bakmakla yükümlü olanlar $\% 48,9^{\prime} l u k$ bir kesimi ihtiva etmektedir. Fakat Tablo 10'da ailesinden yardım almayı düşünebileceğini ifade eden katılımcıların ailede bakmakla yükümlü olduğu kişi sayısı \%44,3’lük bir kesimi 4 ve üzeri sayıya bakmakla sorumlu olanlar \%55,7'lik bir kesimi oluşturmaktadır. Buna göre radikal farklılıklar olmasa da kalabalık bir aileye bakmakla yükümlü olan esnaflar aileden işgücü yardımı almak noktasında daha belirgin imkânlara ve beklentilere sahiptirler denilebilir.

Tablo 12. Kriz zamanlarında "devlete borçlanmayı düşünürüm" diyenlerin, devlet kurumlarının esnaflara yönelik faaliyetlerinden haberdar olma oranları

\begin{tabular}{|l|c|c|c|}
\hline Devlet Faaliyetleri & Sayı & Yüzde & Genel Yüzde \\
\hline Haberdarım & 18 & 42,9 & 32,1 \\
\hline Kısmen haberdarım & 9 & 21,4 & 27,6 \\
\hline Haberdar değilim & 15 & 35,7 & 40,3 \\
\hline Toplam & $\mathbf{4 2}$ & $\mathbf{1 0 0}$ & $\mathbf{1 0 0}$ \\
\hline
\end{tabular}

Tablo 12' de devlete borçlanmayı düşünen katılımcıların devlet kurumlarının esnaflara yönelik faaliyetlerinden haberdar olma durumları çapraz tablo ile sorgulanmıştır. Oranlar itibari ile yüksek farklılıklar olmasa da esnafların genelinin \%32,1'i devlet kurumlarının esnaflara yönelik faaliyetlerinden haberdar iken; devlete borçlanmayı düşünenler $\% 42,9$ ile devlet kurumlarının esnaflara yönelik faaliyetlerinden daha fazla haberdardırlar. Bu durum esnafların haberdar olma durumlarına oranla, devletten kredi, hibe ya da başka yollarla borç alma düşünceleri arasında bir bağlantı olduğunu göstermektedir. Benzer bir oran kanun yönetmelik vs.'den, KOSGEB faaliyetlerinden, hibe olanaklarından ve kredi olanaklarından haberdar olma durumları için de geçerlidir. Yani esnaflar; kurum, kuruluşlar ve yönetmeliklere dair bilgi sahibi olmalarıla orantılı olarak onlardan yardım alma beklentilerini yüksek tutmaktadırlar. 
Tablo 13. Kriz zamanlarında "devlete borçlanmayı düşünürüm" diyenlerin, devlet kurumlarının iyi bir esnafın yetişmesi için çalışıp çalışmadığına dair kanaatleri

\begin{tabular}{|l|c|c|c|}
\hline Devlet Kurumları & Sayı & Yüzde & Genel Yüzde \\
\hline Çalışıyor & 16 & 37,2 & 29,1 \\
\hline Çalışmıyor & 19 & 44,2 & 52,9 \\
\hline Kararsızım & 8 & 18,6 & 18 \\
\hline Toplam & $\mathbf{4 3}$ & $\mathbf{1 0 0}$ & $\mathbf{1 0 0}$ \\
\hline
\end{tabular}

Esnafların \%29,1'si devlet kurumlarının iyi bir esnafın yetişmesi için çalıştığını söyler iken \%52,9 çalışmıyor, \%18'i de kararsızım şeklinde beyanat vermişlerdir. Ancak tablo 13'e göre kriz zamanlarında devletten borç alırım diyenlerin \%37,2'si devletin çalıştığına inanmaktadır. 29,1'lik genel rakamının bu dilim içerisinde \%37,2'ye çıkmış olması; devlet kurumlarının çalıştığına inanan esnafların, söz konusu kurumlardan borç/yardım alabilme umutlarını nispeten güçlendirdiğini göstermektedir. Öte yandan katılımcıların \%44,2'si devlet kurumlarının hem çalışmadığına inanmakta hem de söz konusu kurumlardan borç alabileceğini ummaktadır.

Tablo 14. Kriz zamanlarında "esnaf arkadaşlardan borç almayı düşünürüm” diyenlerin, "piknik, gezi, yemek" gibi organizasyonlara katılım" oranları

\begin{tabular}{|l|c|c|c|}
\hline Gezi Piknik vs. Organizasyon & Sayı & Yüzde & Genel Yüzde \\
\hline Katılanlar & 19 & 35,8 & 20,4 \\
\hline Katılmayanlar & 34 & 64,2 & 79,6 \\
\hline Toplam & $\mathbf{5 0}$ & $\mathbf{1 0 0}$ & $\mathbf{1 0 0}$ \\
\hline
\end{tabular}

Tablo 14. dikkat çekici rakamlar ortaya koymaktadır. Esnafların geneli \%20,4 oranında gezi piknik vs. organizasyonlara katılım sağlamışlar iken; kriz zamanlarında "esnaf arkadaşlardan borç almayı düşünürüm” diyenler, \%35,8 gibi bir rakamla söz konusu organizasyonlara katılım sağlamışlardır. Bu tablo gösteriyor ki birliktelik içinde bulunan esnaflar yani sosyal sermaye göstergeleri yüksek olan esnaflar, ekonomik kriz zamanlarında sosyal sermayeyi ekonomik sermayeye tahvil edebilecek ümidi taşımaktadırlar.

Tablo 15. Kriz zamanlarında "işçi çıkarmayı düşünürüm” diyenlerin, ne kadar işçi çalıştırdıklarının oransal ifadesi

\begin{tabular}{|l|c|c|c|}
\hline Çalıştırdı̆̆1 işçi sayısı & Sayı & Yüzde & Genel Yüzde \\
\hline $\mathbf{0 - 3}$ & 12 & 24,5 & 82,2 \\
\hline $\mathbf{4 - 7}$ & 11 & 22,4 & 14,2 \\
\hline $\mathbf{8 - 1 1}$ & 12 & 24,5 & 1,9 \\
\hline $\mathbf{1 2}$ ve üzeri & 14 & 28,6 & 1,7 \\
\hline Toplam & $\mathbf{4 9}$ & $\mathbf{1 0 0}$ & $\mathbf{1 0 0}$ \\
\hline
\end{tabular}

Çalışmanın en dikkat çekici tablolarından birisi de tablo 15'tir. 450 esnaf içerisinden 49 kişi $(\% 10,9)$ kriz zamanlarında işçi çıkarabileceğini ifade etmektedirler (Bkz. Tablo 10). Fakat 
işçi çıkarmayı düşünürüm ifadesini kullananların kendi içerisindeki dağılımına bakıldığında bu dilimin çoğunluğunu 4 ve üzeri işçi çalıştıranların teşkil ettiği görülmektedir. Yani işverenin çalıştırdığı işçi sayısı arttıkça, kriz zamanlarında onları işten çıkarma eğilimleri de artmaktadır. Az işçi çalıştıran esnafların, krizle mücadele etme stratejileri arasında, işçi çıkarmak eğilimi daha azdır.

\section{SONUÇ VE ÖNERILER}

Sosyal sermaye çalı̧̧maları gerek batı toplumlarında gerekse de Türkiye'de çeşitli değişkenler üzerinden yapılmaktadır. Bugün sosyal sermaye kavramının toplumsal yaşamın tam olarak hangi boyutlarını tarif etmek maksadıyla kullanıldığı belli olmamakla beraber, kavramın üzerinde nispi bir konsensüs oluşmuştur. Kavramın muhtevasından ziyade önemi daha çok vurgulanan bir unsur olarak karşımıza çıkmaktadır. Kavramın önemi, modern toplumların içinde bulunduğu bir kısım sorun alanlarını doğrudan işaret etmesinden kaynaklanmaktadır. Bu sorun alanlarının çeşitli düzeyde politik ajandalar içerisinde de tanımlandığı, modern insanın bu sorunlardan muzadarip olduğu ve bu sorunların üstesinden gelmek için çeşitli yollara başvurulduğu görülmektedir. Bu noktada kadim bir gerçekliği ihtiva eden ama henüz yeni bir kavramsallaştırma sayılan sosyal sermaye terkibi, son zamanlarda daha da önemli bir fenomen olarak karşımıza çıkmaktadır. Mezkur sorun alanları içerisinde modern kapitalist sistemin ürünü olarak görülebilecek bir kısım kişisel ve toplumsal çıkmazlar, önemli bir alanı ihtiva etmektedir. Bu noktada ekonomik sistemin bir bütün olarak hem davranış bazında hem de makro-mikro ekonomik sorunlar bazında modern insanı bir dizi problemlerle karşı karşıya bıraktığı bilinmektedir. Türkiye'nin 1980'lerden sonra neo-liberal ekonomik sisteme angaje olması, belirli oranda davranışsal ve iktisadi bir dönüşüme teşne olmuştur. Bu noktada özellikle küçük üreticinin yani esnaf veya zanaatkar olarak nitelendirilen bireylerin yaşamış olduğu sorunlar, diğerlerinin yaşadıklarına nazaran daha da farklılık arz etmektedir. Sorunların farklı olması çözüm yollarını da büyük oranda farklılaştırmış, esnaflar ile büyük işletme sahiplerinin hayata tutunma pratikleri sosyoloji için bir araştırma konusu haline gelmiştir.

Dünyada sosyal sermaye rezervlerini ölçen çeşitli kurum ve kuruluşların parametrelerinden nispeten bağımsız olarak görüldü ki, Türk vatandaşları içerisindeki esnaf ve zanaatkarın sosyal sermaye rezervi, formel ağlar üzerinden değil informel ağlar üzerinden kendisini göstermektedir. Kapitalist öğretinin neden olduğu bir dizi problemler, esnafların kendi içerisinde geliştirmiş olduğu çeşitli süspanse yollarıyla aşılmakta, esnaflar yakın sosyal çevresi ile önemli oranda bir ilişkisellik ortaya koymaktadır. Bu noktada esnaflar kendi ağlarını kullanma imkanı ve becerilerine göre ekonomik sistem içerisinde tutunabilmekte, büyüyebilmekte ve küçülebilemektedir. Bu durum eşit ekonomik sermayeye sahip olduğu varsayılan esnafların neden aynı oranda büyüyemediğinin anlaşılması açısından da önem teşkil etmektedir. Bu noktada yapılan saha çalışmasından elde edilen sonuçlar genel olarak şöyle sıralanabilir:

1- Esnafların esnaf odalarını, mesleki dernek ve vakıfları, dini guruplar ve cemaatleri ziyaret etme sıklı̆̆ ve onların faliyetlerinden haberdar olma oranları; söz konusu kurumların çalışıp çalışmadığına dair olumlu bir kanaat vermesine neden olmaktadır.

2- Esnaflara yönelik kurum ve kuruluşlarla kurulan ilişki, kırsal kökenli esnaf bir tarafa kentli esnaf için dahi düşük düzeylerdedir. Bu noktada özellikle yerel-ulusal basında esnaflara yönelik faaliyet haberlerinin esnaflarda karşılığının olmadığı görülmektedir. 
3- Esnaflar idealist bir bakış açısıyla, kendi aralarındaki ilişkinin daha fazla gelişmesi gerektiği noktasında oldukça güçlü kanaatlere sahiptir. Ancak mevcut ilişki düzeyi ideal olanın altındadır.

4- Uluslarası güven ölçekleri Türk toplumunun genel güven düzeylerini gösterme açısından yetersizdir. Esnafların birbirine olan güven düzeyleri dışardakilere (ötekine) nispetle çok daha yüksektir.

5- Esnafların krizle mücadele etme stratejileri arasında kendisi veya ailesi sorunların üstesinden gelemez ise formel kurum ve kuruluşlara başvurmaktadırlar. Bu durum birincil ilişkilerin ciddi bir sosyal sermaye rezervine sahip olduğunu göstermektedir.

6- Kurum, kuruluş veya yönetmelik gibi esnaflığa dair birtakım unsurların esnaflar tarafından bilinmesi, söz konusu unsurları, esnaflar için kriz zamanlarında bir süspanse aracına dönüştürebilmektedir. Yani esnaflar bilgi sahibi oldukça yardım beklentileri ve başvuruları da artmaktadır.

7- Sosyal sermaye göstergeleri yüksek olan esnaflar, ekonomik kriz zamanlarında kurmuş olduğu ağları aktif olarak kullanmaya daha yatkındırlar.

8- Az işçi çalıştıran esnafların orantısal olarak kriz zamanlarında daha az işçi çıkarma eğiliminde oldukları görülmüştür. Öte yandan çok işçi çalıştıranlar, kriz zamanlarında işçi çıkarmayı krizle mücadele etme stratejisi olarak görme eğilimine sahiptirler.

Tüm bu sonuçlar gösteriyor ki esnafların sosyal sermaye rezervleri birincil ilişkilerin daha yoğun yaşandı̆̆ı; aile, akraba, arkadaş ve komşu gibi yakın çevre içerisinde gömülüdür. Türkiye'de bir ekonomi fenomeni olarak esnafların açıklanmasında sosyal sermaye "kayıp halka" olarak görülebilecek iken; sosyal sermaye kavramının kayıp halkasını da informel ağlar teşkil etmektedir. Bu noktada esnaflara dair faaliyet yürütmekle memur kurum ve kuruluşların, esnafların beklentilerini tam anlamıla karşılayamadığı anlaşılmaktadır. Bu kurumlar için şunlar önerilebilir.

1- Sektörel olarak aynı iş kolunda mesai teksif eden esnafların aynı ortamlarda kaynaştırılması sağlanabilir. Böylece olması umulan kaynaşmanın esnafları kriz zamanlarında dayanışmaya sevk etmesi beklenebilir. Esnaflar arasında borç alıp borç verme; rızaya bağlı olarak işçi geçişlerini sağlama; esnafların işbölümü üzerinde uzmanlaşmaya yönelik tutumlarını geliştirme; taşeronlaşma marifetiyle kriz zamanlarında mücadele etme imkânı bulamayan esnafa geçici işler sağlama; bireyselleşmenin neden olmuş olduğu psişik sorunların üstesinden gelme imkânlarının doğması daha muhtemel olur.

2- Esnaflara yönelik faaliyet yürütmekle memur kurum ve kuruluşların aldıkları bağış, aidat veya ücretin şeffaf bir şekilde hangi amaçlar için kullanıldığının belgelenmesi ve bu belgelerin esnaflara sadeleşmiş bir biçimde ulaştırılması gerekmektedir. Söz konusu kuruluşların yapmış oldukları faaliyetler için dahi yeterli bütçeyi denkleştirmekte güçlük çektiği bilinmektedir. Ancak mevcut bütçe üzerinde tasarrufu bulunan kurumlar bu bütçeyi nereye teksif ettiğini bildirmekle memurdurlar. Bu durumun kurumlar ve esnaf arasındaki güven düzeyini daha yükseklere çıkarması beklenebilir.

Mekân, hammadde, makine ve işçiye dayalı sorunların üstesinden gelmek için bir dizi organizasyonlar, fuarlar ve kooperatifler oluşturularak kronikleşmiş esnaf sorunlarının üstesinden gelmek için belediyeler, Hazine ve Maliye ve Ticaret Bakanlığı gibi kurumlarla birlikte ya da onların hamiliğinde organizasyonlar yapılmalıdır. Böylece yapısal olan bir 
takım sorunların yüksek ekonomik maliyetler gerektirmeden üstesinden gelmenin imkânı doğmuş olur.

\section{SUMMARY}

This study focuses on social capital reservoirs of tradesmen. Previous studies have generally framed artisanship and craftsmanship as an economic phenomenon and analysed it in the context of economic capital. Current study, however, approaches artisanship and craftsmanship in the context of social capital in addition to economic capital. Due to this, we emphasize that tradesmen represent a missing-link in the literature of social capital researches. Without neglecting the importance of economic capital, this study is designed to describe the relationship between social capital and processes of economic growth or downsizing. Accordingly, this paper consists of four main sections. The first section emphasizes the central role of social capital in human relations. Here, it is suggested that in addition to economic capital, social actors need cultural, human and social capital in order to attain psycho-social positions they desire. In the second section, we propose that social capital is capable of transforming into economic capital. Also, it is suggested that social capital can be as important as the economic capital in processes of production, services and distribution. The third section emphasizes that artisanship and craftsmanship in Turkey can be defined by traits produced by the distinct relationship between capitalism and tradition. This means that the tradesmen in Turkey possess a social capital reservoir shaped by informal networks. The final section contains analysis and interpretation of the survey research conducted with 450 tradesmen in Konya, Turkey. Here, the analysis focuses on the social networks within which the tradesmen interact, the intensity of these interactions, the interrelations of tradesmen, and finally indicators of social trust. Finally, we describe the strategies developed by tradesmen in periods of economic crisis and, the role and extent of social capital mobilization within these strategies.

In order to clarify the context and the conceptual background of the research, defining the boundaries and uses of the concept of social capital is necessary. Following a theoretical discussion including the works of Bourdieu, Putnam, Coleman and others, we eventually define social capital as the total set of social relations based on formal and informal networks possessed by social actors. We contend that the idea of social capital occupies the central role in our study because any given social environment includes social mechanisms like solidarity, division of labor, bureaucracy etc. to sustain itself. Individuals are equipped with potential power as a result of reciprocal relations within a social environment. With their potential power, individuals develop strategies to cope with the challenges they can possibly face. Consequently, we assume that the tradesmen have to face with such challenges and social capital and networks are important resources to deal with them. At this point, it is necessary to ask how tradesmen use their social capital and network in their business-related interactions as well as the possibility to convert their social capital to economical capital. We argue that both questions have a positive answer, which means that the tradesmen do convert social capital and networks can be converted into economical capital. It should be noted that craftsmanship and artisanship represent traditional forms of work in capitalist systems. In the context of Turkish modernization, it is possible to state that both craftsmanship and artisanship as traditional forms are reproduced within the modern social and economic structure. Therefore, it is possible to assume that the present craftsmanship culture, which depicts a sui generis pattern, has been generated in Turkey. For instance, they 
utilize modern banking practices alongside their social networks which include their family, relatives and friends. Also, in periods of economic crisis, whether this crisis is rooted at the global, national or individual levels, family members may join the workforce in the workplace. Furthermore, employee-employer relations in such workplaces are usually established on an informal basis. The craftsmen may strengthen their professional abilities by making use of modern institutions and practices like using credit from private or state agencies, foundations and associations to counter economic crises or develop their businesses. In short, we can say that formal and informal networks have a significantly modified role and functioning in craftsmanship practices than traditional times.

As we explained above, the central argument in this research is that the craftsmen sustain their economic activities using their traditional modes of conduct within a moderncapitalist economical system. We also maintain that business-related problems are solved through individual-social and modern-traditional strategies and connections. After initial research, experiences and observations, we prepared a survey which includes questions designed to measure how often a tradesman make use of formal and informal networks; whether they think institutions and organizations are instrumental in providing the needed training for the tradesman or not; how much the tradesmen are informed about activities of some organizations which might be useful for them, etc. Since this study is mainly a descriptive research, no hypotheses are tested although we hold some implicit hypotheses as outlined above. The questions included in the survey are prepared following a thorough examination of related works of the OECD, World Bank and World Values Survey. Finally, the sample of this research is formed with the tradesmen located in Konya, a fairly industrial and agricultural city in central Turkey.

Following the data collection and analysis in Konya, we have reached some interesting and meaningful conclusions. First, interactions with formal and religious associations as well as being informed about their activities positively correlate with positive views about these associations. Secondly, interactions with tradesmen-oriented associations and institutions is rather low both for tradesmen of urban and rural origin. Third, the tradesmen strongly believe that developing the informal relations among themselves is crucial, although they consider the current level of relations insufficient. Fourth, the level of trust among the tradesmen is higher than the trust levels in the society. Here, it is crucial to point out that international scales of trust are found to be insufficient in measuring trust levels in Turkish society. Fifth, the tradesmen prioritize relations with other tradesmen, family members or friends over formal institutions and associations in coping with business related crises. Sixth, being informed about the institutions, associations and regulations increases their likelihood of being used in times of crisis. In other words, there is a positive correlation between level of information and applications to and expectations from formal structures. Seventh, tradesmen with higher levels of social capital tend to utilize their networks more when facing economic challenge. Finally, tradesmen employing fewer workers tend to lay off fewer employees in the context of economic crisis. On the other hand, lay-offs are seen as a primary strategy by those employing more workers.

All these results demonstrate that primary social relations are the most important reservoir in the context of social capital. In other words, Turkish tradesmen primarily use their informal connections rather than formal networks in crisis situations. 


\section{KAYNAKÇA}

Akgül, D. (2017). Ahilik kültüründeki etik ilkelerin günümüz işletmelerine yansıması. Ahi Evran Üniversitesi İktisadi ve İdari Bilimler Fakültesi Dergisi, 1(1), 8-26.

Aksan, G. (2015). Yoksulluk ve dayanışma ağları. Konya: Çizgi Kitabevi.

Ardahan, F. (2014). Bireylerin sosyal sermaye profili antalya örneği. Akademik Sosyal Araştırmalar Dergisi, 2(8), 38-56.

Aslan, S. (2016). Türkiye'de sosyal sermayenin bileşenlerinden güven hakkında bir değerlendirme. C.Ü İktisadi ve İdari Bilimler Dergisi, 17(2), 181-204.

Aslanderen, M. (2016). Esnaf ve sanatkârlarm ahilik değerlerine sahiplik düzeylerinin değerlendirilmesi (Kırşehir örneği) (Yayımlanmamış Yüksek Lisans Tezi). Kırşehir Ahi Evran Üniversitesi Sosyal Bilimler Enstitüsü, Kırşehir.

Aydemir, M. A. (2011). Sosyal sermaye topluluk duygusu ve sosyal sermaye araştırması. Konya: Çizgi Kitabevi.

Aydemir, M. A. (2016). Sosyal alanın tipleştirilmesi toplumsal tipler. M. A. Aydemir içinde, Toplumsal Tipler (s. 11-32). İstanbul: Açllım Kitap.

Aydemir, M. A. ve Özşahin, M. C. (2011). Türk demokrasisinde kayıp halkayı keşfetmek Türkiye örneği üzerinden sosyal sermaye-demokrasi bağlantısını yeniden düşünmek. Akademik Incelemeler Dergisi, 6(1), 41-87.

Aydemir, M. A. ve Tecim, E. (2012). Türk toplumunda aile ve dinin sosyal sermaye potansiyeli. Selçuk Üniversitesi Sosyal Bilimler Enstitüsü Dergisi, 28, 43-59.

Aydın, G. (2014). Esnaf ve sanatkarların istihdama ilişkin sorunlarının incelenmesi (Yayımlanmamış Yüksek Lisans Tezi). Dokuz Eylül Üniversitesi Sosyal Bilimler Enstitüsü, İzmir.

Baykul, A. (2009). Isparta il merkezindeki esnaf sorunlar ve esnafin yerel ekonomi ile ilişkisi (Yayımlanmamış Yüksek Lisanst Tezi). Süleyman Demirel Üniversitesi Sosyal Bilimler Enstitüsü, Isparta.

Becker, H. S. (2015). Hariciler (outsiders) bir sapkınlık sosyolojisi çalışması. (Ş. Geniş ve L. Ünsaldı, Çev.) Ankara: Heretik Yayınları.

Bourdieu, P. (2010). Sermaye biçimleri. M. M. Şahin ve A. Z. Ünal içinde, Sosyal Sermaye Kuram Uygulama Eleştiri (s. 45-76). İstanbul: Değişim Yayınları.

Bourdieu, P. ve Passerson, J. C. (2015). Yeniden üretim eğitim sistemine ilişkin bir teorinin ilkeleri. (A. Sümer, L. Ünsaldı ve Ö. Akkaya, Çev.) Ankara: Heretik Yayınları.

Coleman, J. S. (2010). Beşeri sermayenin yaratımında sosyal sermaye. M. M. Şahin ve A. Z. Ünal içinde, Sosyal Sermaye Kuram Uygulama Eleştiri (s. 77-120). İstanbul: Değişim Yayınları.

Ekşi, H. (2009). Sosyal sermaye-önemi, üretimi ve ölçümü- üzerine bir alan araştırması (Yayımlanmamış Doktora Tezi). Selçuk Üniversitesi Sosyal Bilimler Enstitüsü. Konya.

Ergin, R. A. (2007). Sosyal sermayenin yöneticiler bağlamında ölçülmesine yönelik konya sanayisinde bir araştırma (Yayımlanmamış Yüksek Lisans Tezi). Selçuk Üniversitesi Fen Bilimleri Enstitüsü, Konya.

Eser, K. ve Gökmen, Ç. E. (2009). Beşeri sermayenin ekonomik gelişme üzerindeki etkileri: Dünya deneyimi ve Türkiye üzerine gözlemler. Sosyal ve Beşeri Bilimler Dergisi, 1(2), 4156.

Field, J. (2008). Sosyal sermaye. (B. Bilgen ve B. Şen, Çev.) İstanbul: İstanbul Bilgi Üniversitesi Yayınları.

Fine, B. (2001). Social capital versus social theory: Political economy and social science at the turn of the millennium. New york: Routledge.

SEFAD, 2019; (41): 313-342 
Goffman, E. (2014). Damga örselenmiş kimliğin idare edilişi üzerine notlar. (Ş. Geniş, vd. Çev.) Ankara: Heretik Yayıncilik.

Gökçen, A. (2013). Cumhuriyetten günümüze Türkiye'de iktisat politikaları ve ekonomik Gelişme. M. Zencirkıran içinde, Dünden Bugüne Türkiye'nin Toplumsal Yapısı (s. 213-242). Bursa: Dora Basım-Yayım.

Grooteart, C. (2010). Sosyal sermaye: Kayıp halka? M. M. Şahin ve A. Z. Ünal içinde, Sosyal Sermaye Kuram Uygulama Eleştiri (s. 221-264). İstanbul: Değişim Yayınları.

Kabadayı, T. (2015). Esnaf ve sânatkarların finansal sorunları: Gümüşhane ilinde bir uygulama (Yayımlanmamış Yüksek Lisans Tezi). Gümüşhane Üniversitesi Sosyal Bilimler Enstitüsü, Gümüşhane.

Kanar, M. (2011). Osmanlı Türkçesi sözlü̆̆ü. Ankara: Say Yayınları.

Karagül, M. ve Masca, M. (2005). Sosyal sermaye üzerine bir inceleme. Ekonomik ve Sosyal Araştırmalar Dergisi, 37-52.

Koç, A. ve Ata, Y. (2012). Sosyal sermaye ve ekonomik büyüme ilişkisi: AB ülkeleri ve Türkiye üzerine ampirik bir inceleme. Süleyman Demirel Üniversitesi İktisadi ve İdari Bilimler Fakültesi Dergisi, 17(1), 199-218.

Lin, N. (2001). Social capital a theory of social structure and action. Australia: Cambridge University Press.

Marcuello-Servós, C. (2007). Networks, trust and social capital: Theoretical and empirical investigations from Europe. International Sociology Review of Books, 2(22), 199-202.

Marcuse, H. (1990). Tek boyutlu insan ileri işleyim toplumunun ideolojisi üzerine incelemeler. (A. Yardımlı, Çev.) İstanbul: İdea Yayınları.

Özuğurlu, M. (2008). Anadolu'da küresel fabrikanın doğuşu yeni işçilik örüntülerinin sosyolojisi. İstanbul: Kalkedon Yayınları.

Putnam, R. (2010). Tek başına bowling amerika'nın azalan sosyal sermayesi. M. M. Şahin ve A. Z. Ünal içinde, Sosyal Sermaye Kuram Uygulama Eleştiri (s. 121-142). İstanbul: Değişim Yayınları.

Reisman, D. (2016). Yalnız kalabalık amerikan toplumsal karekterinin değişimi üzerine bir inceleme. (Y. Erdem, Çev.) Ankara: Heretik Yayınları.

Sabanc1, G. (2017). http://www.hurriyet.com.tr/ekonomi/turkiyedeki-isletmelerin-yuzde-95i-ailesirketi-40599291. 05 12, 2018 tarihinde http://www.hurriyet.com.tr/ekonomi/turkiyedekiisletmelerin-yuzde-95i-aile-sirketi-40599291 adresinden alınd1.

Schultz, T. W. (1961). Investment in human capital. The American Economic Review, 1-17.

Simmel, G. (2009). Bireysellik ve kültür (T. Birkan, Çev.). İstanbul: Metis Yayınları.

Şen, E. (2009). Esnaf Kefalet Kredilerinin Türkiye'deki Mekansal Dă̆ılışı ve Sonuçları (Yayınlanmamış Yüksek Lisans Tezi). İstanbul Üniversitesi Sosyal Bilimler Enstitüsü, İstanbul.

Taştan, S. B. (2015). Örgütsel güven ve sosyal adalet algisının örgütlerde sosyal sermaye yapısı ile ilişkilendirilmesi. Eskişehir Osmangazi Üniversitesi Sosyal Bilimler Enstitüsü Dergisi, 16(2), 13-58.

Tecim, E. (2011). Sosyal güven sosyal sermaye ve dindarlık çalı̧ması. Konya: Çizgi Kitabevi.

Uysal, M. (2016). Esnaflarda meslek ahlakı ve dindarlık (Isparta örneği) (Yayımlanmamış Yüksek Lisans Tezi). Süleyman Demirel Üniversitesi Sosyal Bilimler Enstitüsü, Isparta.

Yetim, N. (2005). Ekonomi ve sosyolojinin yeni bir kavşakta buluşması: sosyal sermaye. Sosyoloji Dergisi, 3(11), 91-106.

Yüksel, K. (2015). İktisadi kalkınmada sosyal sermayenin rolü: Çorum iline yönelik bir analiz (Yayımlanmamış Yüksek Lisans Tezi). Hitit Üniversitesi Sosyal Bilimler Enstitüsü, Çorum. 